\title{
Evolution of Migmatitic Granulite Complexes: Implications from Lapland Granulite Belt, Part I: Metamorphic geology
}

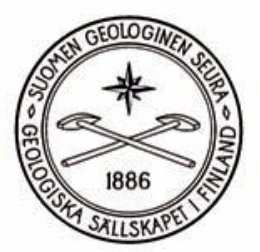

\author{
Pekka Tuisku ${ }^{1) *}$, Pertitu Mikkola ${ }^{2)}$ and Hannu Huhma ${ }^{3)}$ \\ ${ }^{1)}$ Department of Geosciences, University of Oulu, P.O. Box 3000, FI-90014 University of Oulu, \\ Finland \\ 2) Geological Survey of Finland, P.O. Box 1237, FI-70211 KUOPIO \\ 3) Geological Survey of Finland, P.O. Box 96, FI-02151 Espoo, Finland
}

\begin{abstract}
The Palaeoproterozoic Lapland granulite belt was juxtaposed between Archaean and Proterozoic terrains in the NE part of the Fennoscandian Shield concurrently with the accretion of Svecofennian arc complexes at $\sim 1.9 \mathrm{Ga}$. The belt consists mainly of aluminous migmatitic metagreywackes. Abundant noritic to enderbitic magmas were intruded concordantly into the metasediments and were probably an important heat source for metamorphism, which took place during the crystallization of the magmas. This is supported by structural and contact relations of metasediments and igneous rocks, and by the lack progressive metamorphic reaction textures in the igneous rock series. The peak of metamorphism took place above the dehydration melting temperature of the biotite-sillimanite-plagioclase-quartz assemblage at $750-850^{\circ} \mathrm{C}$ and $5-8.5 \mathrm{kbar}$ which lead to formation of a restitic palaeosome and peraluminous granitic melt in metapelites. Subsequently, the rocks were decompressed and cooled below the wet melting temperature of pelitic rocks $\left(650^{\circ} \mathrm{C}\right)$ under the stability field of andalusite coexisting with potassium feldspar (2-3 kbar). Cooling was accompanied by the crystallization of the neosomes, often carrying aluminium-rich phases. Postmetamorphic duplexing of the LGB is clearly seen in the distribution of calculated PT conditions.
\end{abstract}

Key words: granulites, Lapland Granulite Belt, migmatites, metasedimentary rocks, metapelite, enderbite, mineralogy, metamorphism, P-T conditions, Paleoproterozoic, Lapland Province, Finland

*Corresponding author e-mail: pekka.tuisku@oulu.fi

\section{Introduction}

The Palaeoproterozoic Lapland granulite belt (LGB) forms an extensive, $400 \mathrm{~km}$ long and $90 \mathrm{~km}$ wide, middle to lower crustal sequence in the NE Fennoscandian (Baltic) Shield (Eskola, 1952; Meriläinen, 1976; Korja et al., 1996). It was earlier thought to consist mainly of acid granulite facies gneisses with only minor basic or intermediate rocks (Mikkola,
1937; Meriläinen, 1965, 1976; Simonen, 1980). Recent bedrock mapping and use of geophysical data (Korja et al., 1996; this study) have shown that, in addition to migmatitic metapelites, intermediate to basic rocks form an important constituent of the belt. These were earlier called the Lapland charnockitic complex (Barbey et al., 1986), but later loosely called 
enderbites or norite-enderbite series according to major igneous rock types (Korja et al., 1996; Fig. 1). Also, the LGB was earlier thought to form part of the Archaean basement complex of the shield (i.e. Simonen, 1980) but later structural (Marker, 1988; Korja et al., 1996) and geochronological data showed that it is in most part a Palaeoproterozoic high-grade mobile belt surrounded by Archaean complexes (Meriläinen, 1976; Bernard-Griffiths et al., 1984; Huhma \& Meriläinen, 1991; Sorjonen-Ward et al., 1994; Tuisku \& Huhma, 1998, 1999; Daly et al., 2001).

The aim of our study was to reveal the metamorphic evolution of the migmatitic metapelites and the igneous series of the LGB. Unraveling the history of the LGB could clarify the nature of the proposed models invoking divergent to convergent, ca. 2.0-1.8 Ga plate tectonic processes in the Fennoscandian Shield (Gaál \& Gorbatschev, 1987). Granulites commonly occur in significant tectonic zones, for example in the internal parts of orogenic belts (Harley, 1989) and plate tectonic and crustal thickening processes were important in the development of high-grade granulite complexes also during the Palaeoproterozoic era (Newton, 1987). The present study could also clarify the possible connection between the tectonic evolution in the NE part of the shield and the evolution in the Svecofennian arc domain, now exposed in the central and SW part of the shield. The geological history of the LGB also has a key role in the interplate correlation of ca. 1.8-2.0 Ga orogenic events between the Canadian and Fennoscandian Shields (Gaál \& Gorbatschev, 1987; Hoffman, 1988, 1989; Bridgwater et al., 1990; Hall et al., 1995).

Because the LGB is lithologically bimodal, unraveling the evolution of the igneous rocks of the LGB and their relation to the metasedimentary migmatites could help to clarify the role of underplating or intraplating processes in the evolution of high-grade complexes in the lower crust.

\section{Geological setting}

The Lapland granulite belt is one of the classical examples of large granulite terrains (Fig. 1). Metased- imentary granulites, ranging in composition from psammitic to pelitic, form the main rock type and are also called khondalites or khondalite series (e.g. Barbey et al., 1986; Korja et al., 1996). The series is composed mostly of acid migmatitic gneisses or kinzigites, which often have a strong S-tectonitic or blastomylonitic structure usually dipping gently to NE, except at the northeastern margin, where the dips are steeply south-westwards. Some quartz-poor or quartz-deficient rocks, called laanilites by Hackman (1905) and Eskola (1952) are found sporadically among metasedimentary granulites.

Two major metasedimentary units contain almost 50 percent of concordant, enderbitic sill-like intrusions, which also are dominantly tectonized (Korja et al., 1996; this study, Fig.1). These have also been called the Lapland charnockitic complex (Barbey et al., 1986). Because norites, orthopyroxene quartz diorites and enderbites form the majority of the plutonic rock series in the LGB, we prefer the term noriteenderbite series. Even opdalites or charno-enderbites are rare and true charnockites (orthopyroxene granites) are not found. Anorthosites are found as one major unit called the Angeli anorthosite massif, covering an area of about $30 \mathrm{~km}^{2}$ (Meriläinen, 1976), and some smaller concordant sheets discovered during this study. Some later, post-orogenic granite intrusions, diabase dikes (Meriläinen, 1976) and one syenite intrusion have also been found in the area of the LGB.

Considering to the size of the LGB, published high quality geochronological data are sparse. According to the available evidence, most of the anorthositic, enderbitic and metapelitic rocks have a Palaeoproterozoic age range from about 2.0 to $1.9 \mathrm{Ga}$ (Meriläinen, 1976; Bernard-Griffiths et al., 1984; Huhma \& Meriläinen, 1991; Sorjonen-Ward et al., 1994; Daly et al., 2001).

The NE and SW sides of the LGB are bordered by thrusts and other deformation zones (Marker, 1988; Korja et al., 1996, Braathen \& Davidsen, 2000). On the SW-side, there is a marginal series containing a tectonic mixture of highly strained, banded rocks, sometimes called the Tanaelv belt (Marker, 1988). It contains some relatively high-pressure rocks, which 


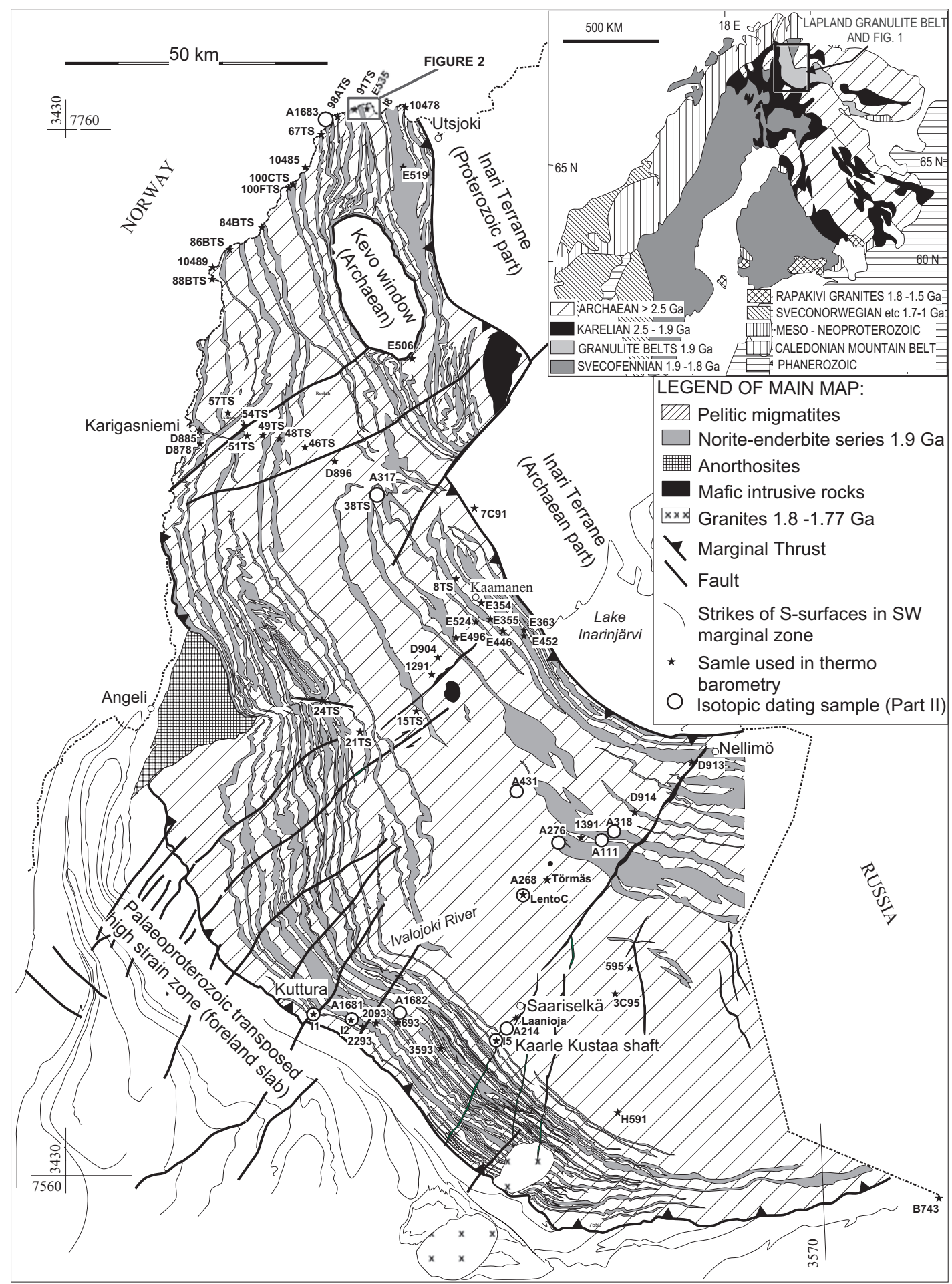

Fig. I. Geological map of the Lapland Granulite Belt in Finnish territory. The map shows major lithological subdivision of the LGB, major tectonic elements of the LGB and adjacent areas, location of samples used for geological thermo-barometry in this paper and, in uppermost part, location of Fig. 2. The sites of samples used for isotopic dating in Part II of this contribution are also shown. The inset shows the location of the study area in the Fennoscandian shield. 


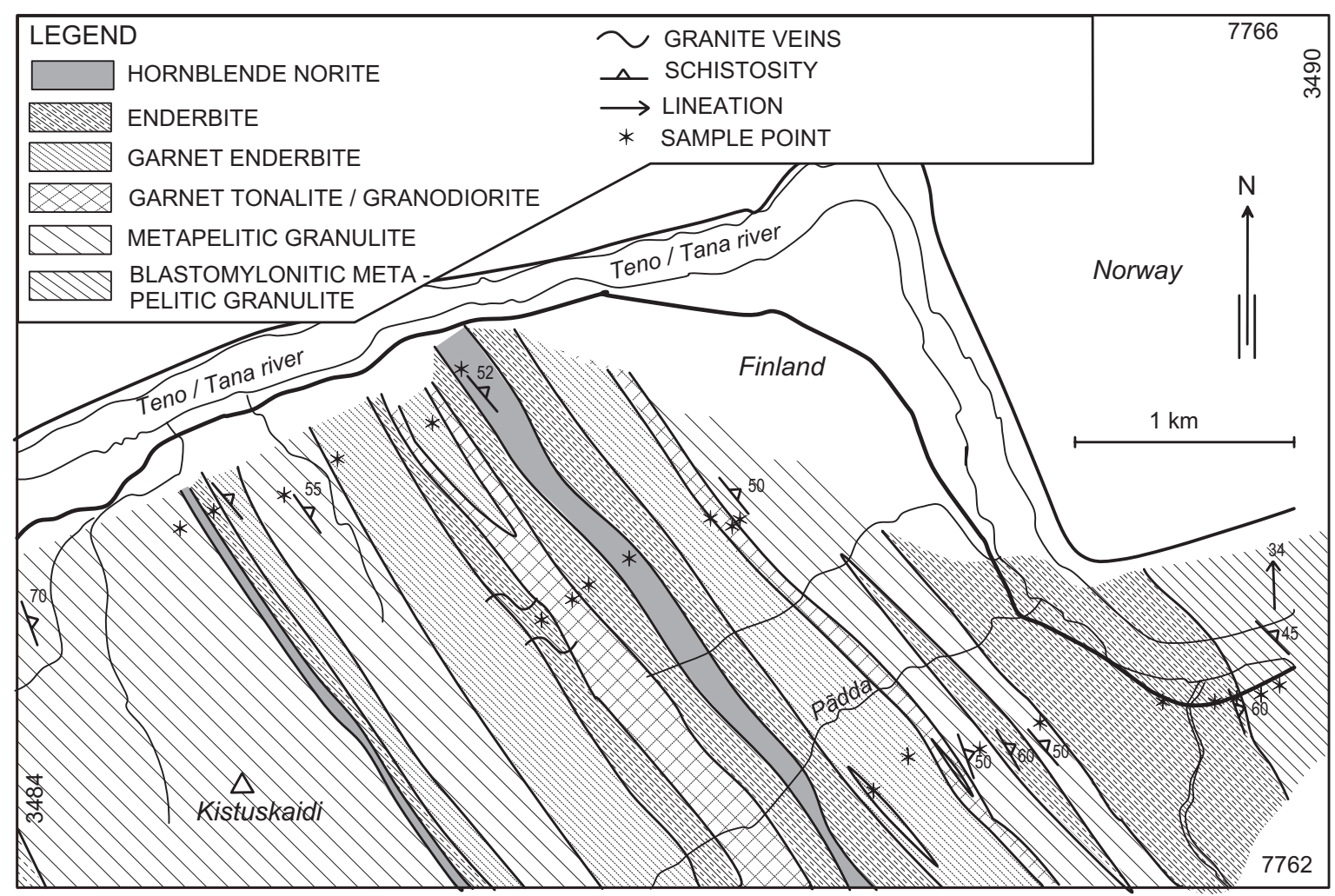

Fig. 2. Map from area, where Tenojoki (Tana elv) canyon crosscuts the LGB and forms the Finnish-Norwegian frontier, showing typical belt parallel layering (banding) and mutual relationships of the rocks.

reached equilibrium at $12 \mathrm{kbar}$. This, together with the intensive transposition during the thrusting of the LGB, suggests that the areas to the SW were included in the subducting slab and formed a foreland area (Tuisku \& Makkonen, 1999). Yet the areas to the SW contain Archaean gneiss complexes (3.1-2.6 Ga) and Palaeoproterozoic, greenstonedominated supracrustal sequences (ca. 2.3-2.0 Ga), which were folded before thrusting of the LGB to the SW (Mikkola, 1937; Meriläinen, 1965, 1976; Kröner et al., 1981; Lehtonen et al., 1992; Korja et al., 1996; Korsman et al., 1997; Braathen \& Davidsen, 2000; Vaasjoki, 2001). In the NE, the LGB is bordered by a gneiss complex, called the Inari Terrane, which is dominantly composed of Neoarchaean basement but also contains notable Palaeoproterozoic granodioritic to gabbroic plutons having an age of 1.95-1.9 Ga (Meriläinen, 1976; Kesola, 1995; Korsman et al. 1997). Younger, ca. 1.77-1.88
Ga granitic plutons intrude discordantly both the LGB and the complexes to the southwest and northeast of it (Meriläinen, 1976; Huhma, 1986; Korsman et al. 1997).

The petrography and petrology of the Lapland granulite belt has been described earlier in several papers, including Eskola (1952), Meriläinen (1976), Hörman et al. (1980, Raith \& Raase (1986), Barbey \& Raith (1990), Leibinger (1996) and Perchuck et al. (2000). However, the only attempts to construct a metamorphic evolution (PT) path were made by Leibinger (1996) and Perchuck et al. (2000) for the cooling stage of the LGB.

\section{Petrography}

Profile mapping was carried on throughout the exposed section of the LGB, usually in major or minor river valleys and hilly highlands. Several samples 


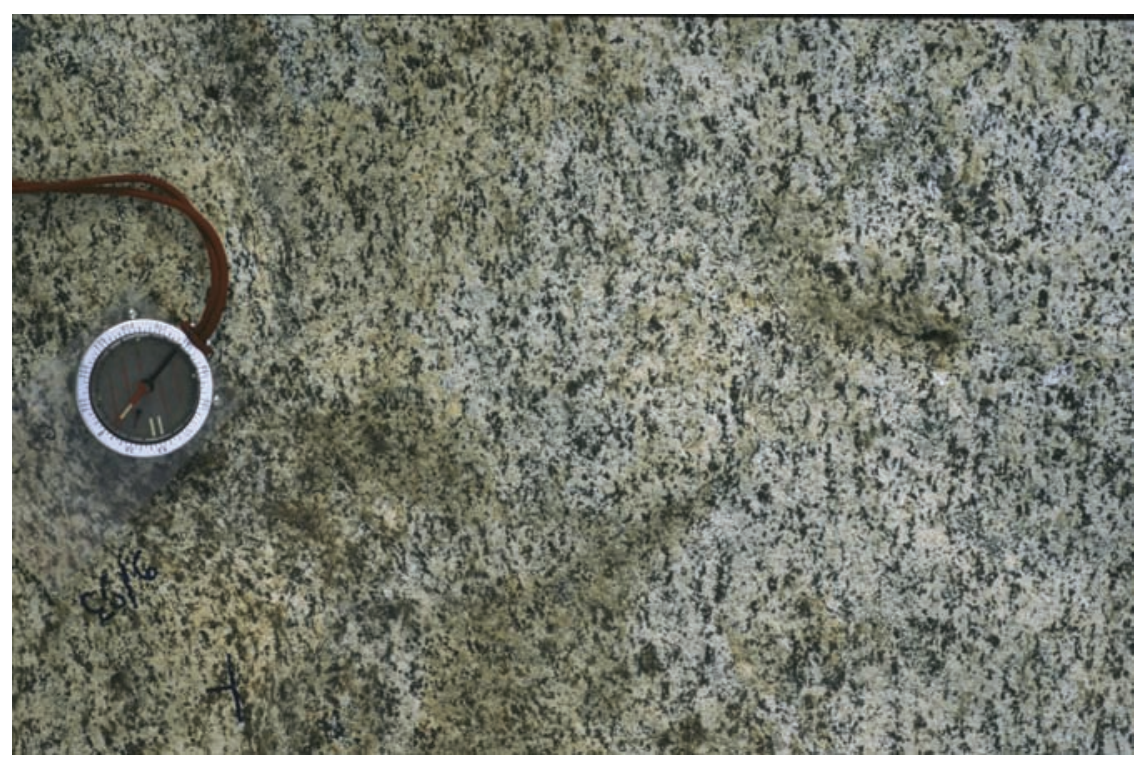

Fig. 3. Enderbite from Vuijeminhaara, representing the most typical, meso- or leucocratic, lineated member of the norite-enderbite series of the LGB.

were selected for thermo barometric work after petrographic studies and/or preliminary probing.

\section{I. Enderbites, norites and related ortho- gneisses}

Enderbites, garnet enderbites and norites are, in that order, the major types of orthogneisses. They occur exclusively as conformable veins or sills in metapelites (Fig. 2). The thickness of the bodies varies from a few centimeters to more than one kilometer. The intrusions are often composed of several rock types, which usually change to each other gradually.

Enderbites occur in almost every mapped intrusion. Andesine, sometimes labradorite, is prominent feldspar and forms a relatively fine-grained granoblastic matrix of the rock. Rodded quartz grains together with polycrystalline aggregates of orthopyroxene give a lineated texture to the rock (Fig. 3). Minor biotite and/or hornblende and clinopyroxene may occur, usually with orthopyroxene. Other accessory minerals include ilmenite, magnetite, apatite, interstitial orthoclase, sulphides, zircon, and monazite.

Garnet enderbites occur generally in a zone between enderbites and metapelites, without clear contacts to either rock types (Fig. 2). Medium-grained, irregularly shaped andesine or labradorite and quartz grains are surrounded by biotite and orthopyroxene and the texture may be mortar. Garnet occurs as poikiloblasts or skeletal grains with inclusions and embayments of quartz, plagioclase, biotite, and, in many cases, rims of plagioclase and orthopyroxene. Accessory phases include orthoclase, ilmenite, magnetite, zircon, apatite and monazite.

Norites usually form conformable layers in enderbite intrusions (Fig 2). They are more melanocratic than enderbites and the plagioclase is labradorite. The texture is granoblastic and the rocks are generally less lineated and more massive and coarsegrained than the enderbites. Orthopyroxene is usually the dominant dark mineral but also substantial amounts of hornblende may occur. Only small amounts of clinopyroxene are encountered and only few rocks are classified as clinopyroxene norites. Biotite may be prominent and accessory minerals include ilmenite, magnetite, sulphides, apatite, and orthoclase.

Garnet tonalites are less abundant than the previously described intrusive rocks. They occur conformably with enderbite intrusions and in contrast to garnet enderbites lack orthopyroxene. They are also more quartz-rich, coarse-grained and less foliated that 


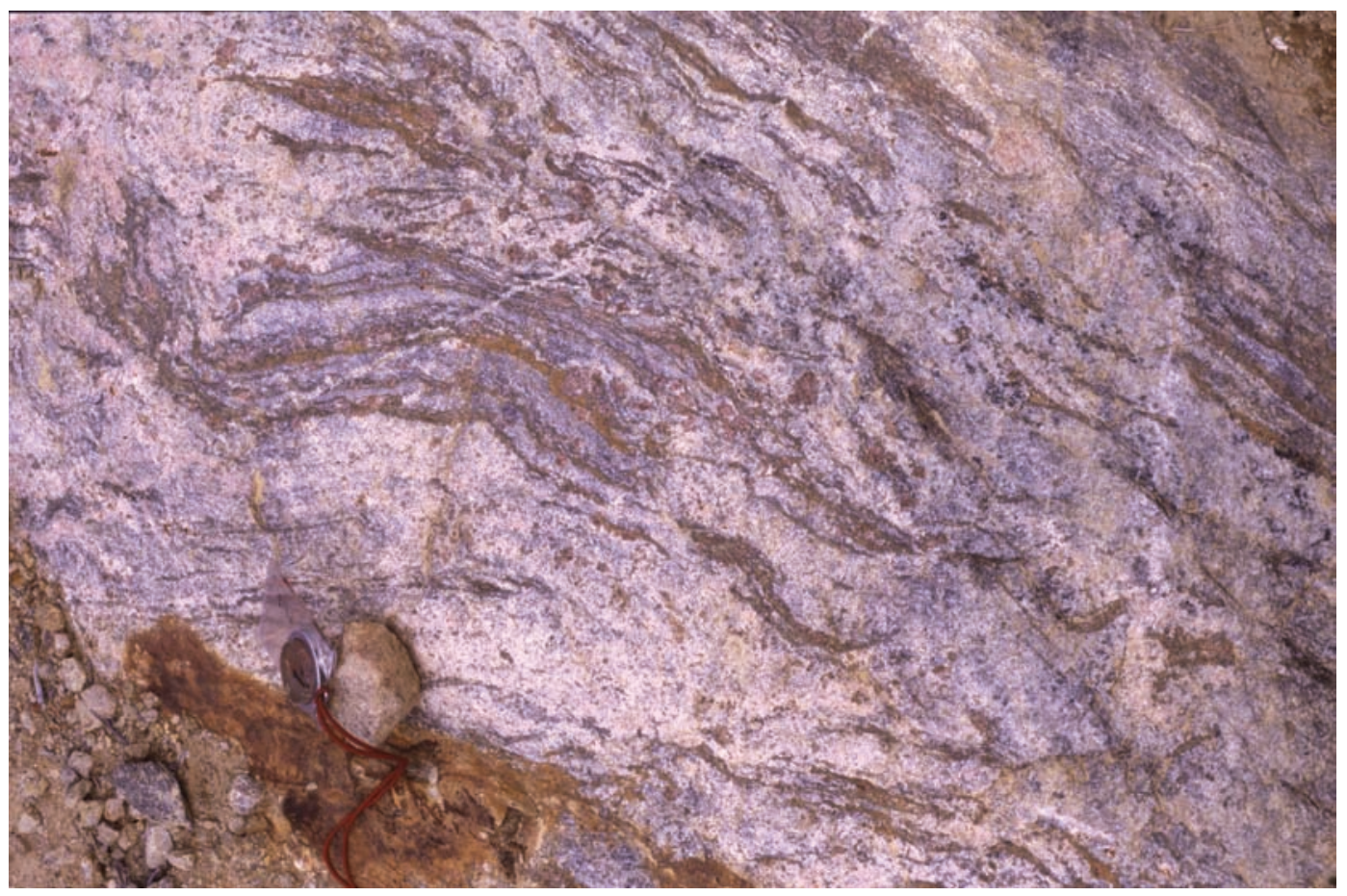

Fig. 4.A schlieren type diatexite from Kaamanen area. The leucosomes consist of garnet and cordierite bearing granite while the mesosomes consist of sillimanite rich garnet-cordierite gneiss.

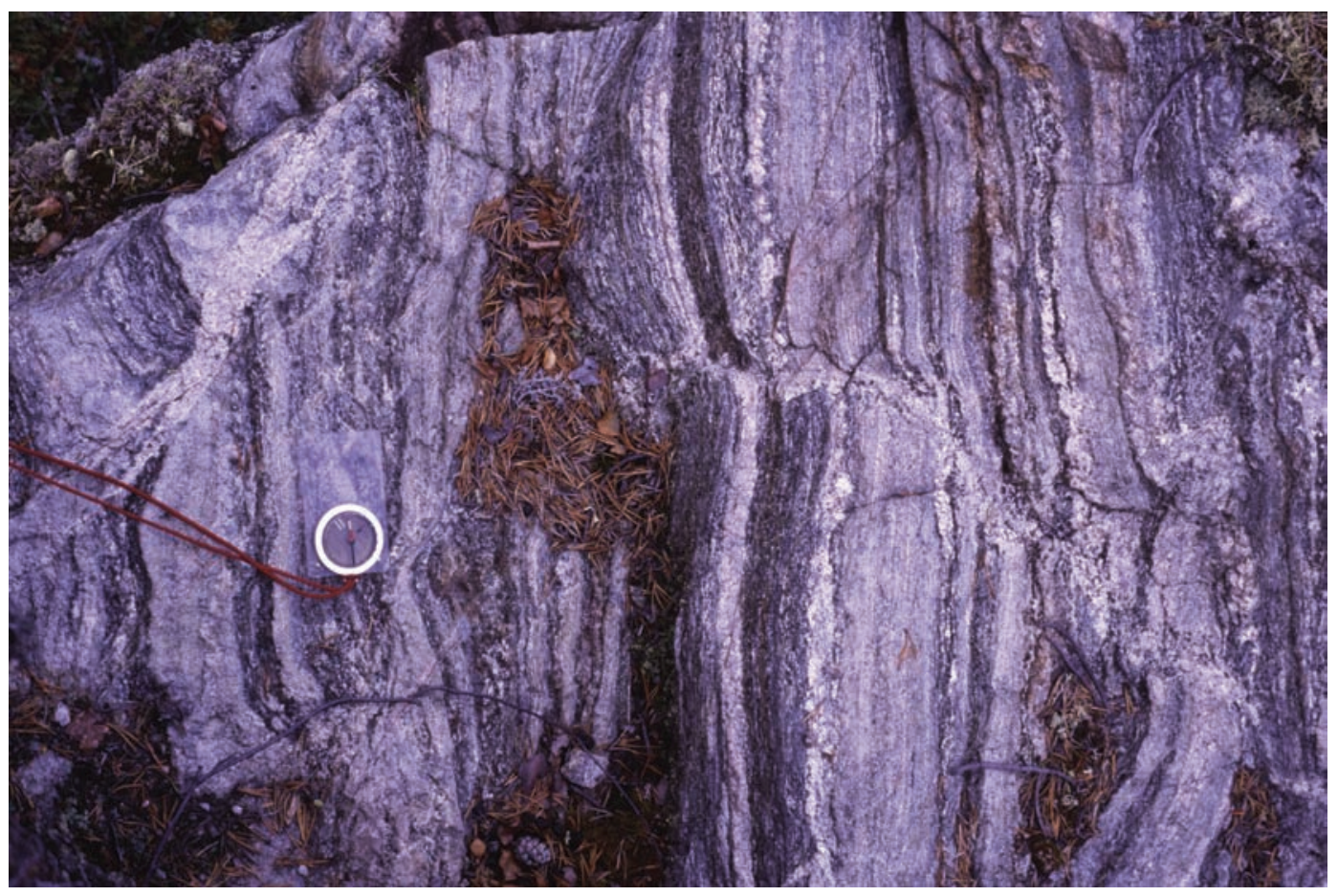

Fig. 5. A Stromatic metatexite from Kaamanen area. The leucosomes consist of granite containing sporadically cordierite and garnet. The mesosome and melanosome bands consist of biotite and sillimanite rich garnet \pm cordierite gneiss. 


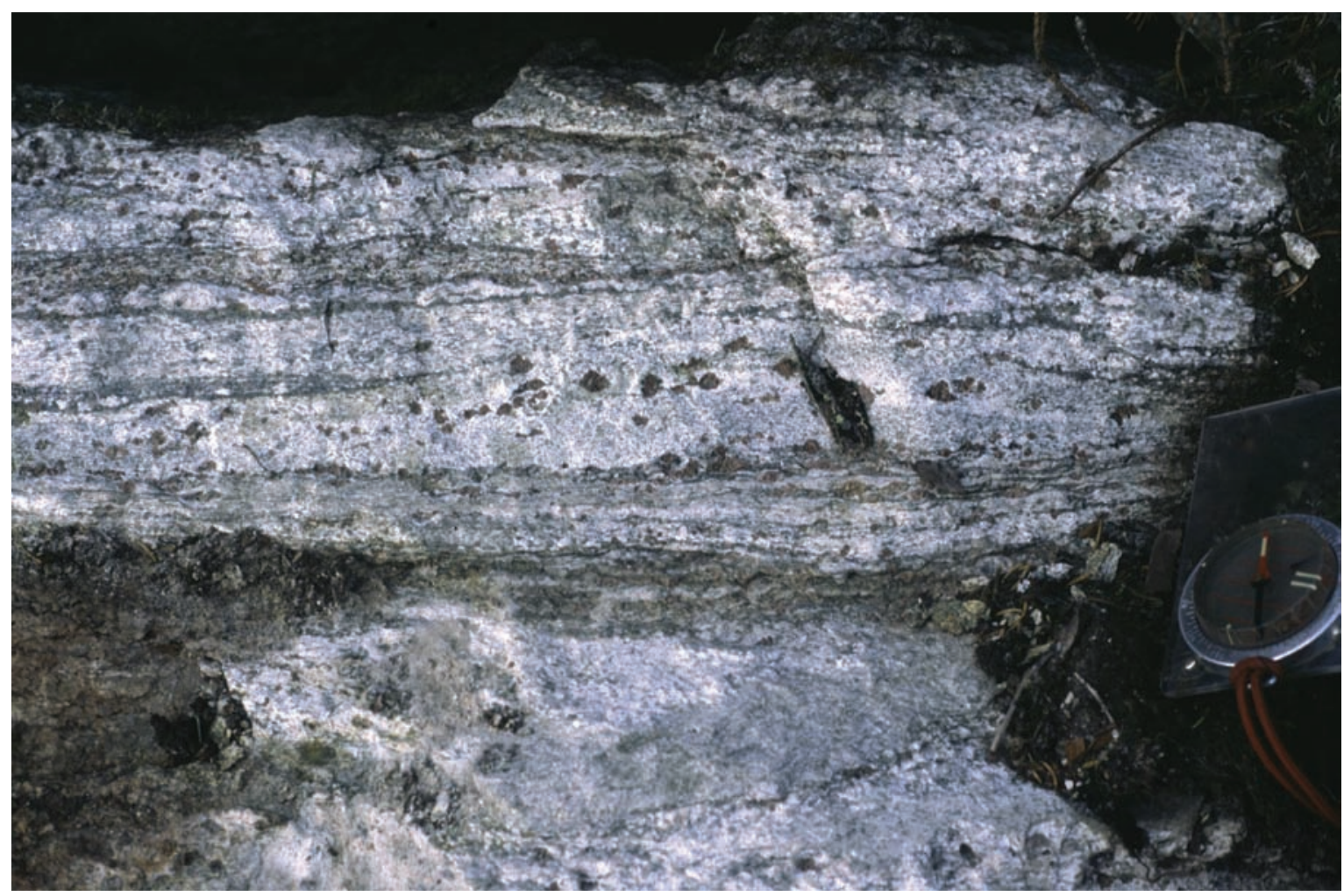

Fig. 6. The most common rock of the Lapland granulite belt, a blastomylonitic intensively banded diatexite, half way between Kuttura and Kaarle Kustaa sampling sites. Leucosomes, having a composition of garnet granite (ligth band in the upper middle part of the photograph), are tectonically mixed with sillimanite rich garnet gneiss (palaeosome) and garnet sillimanite bands (melanosome).

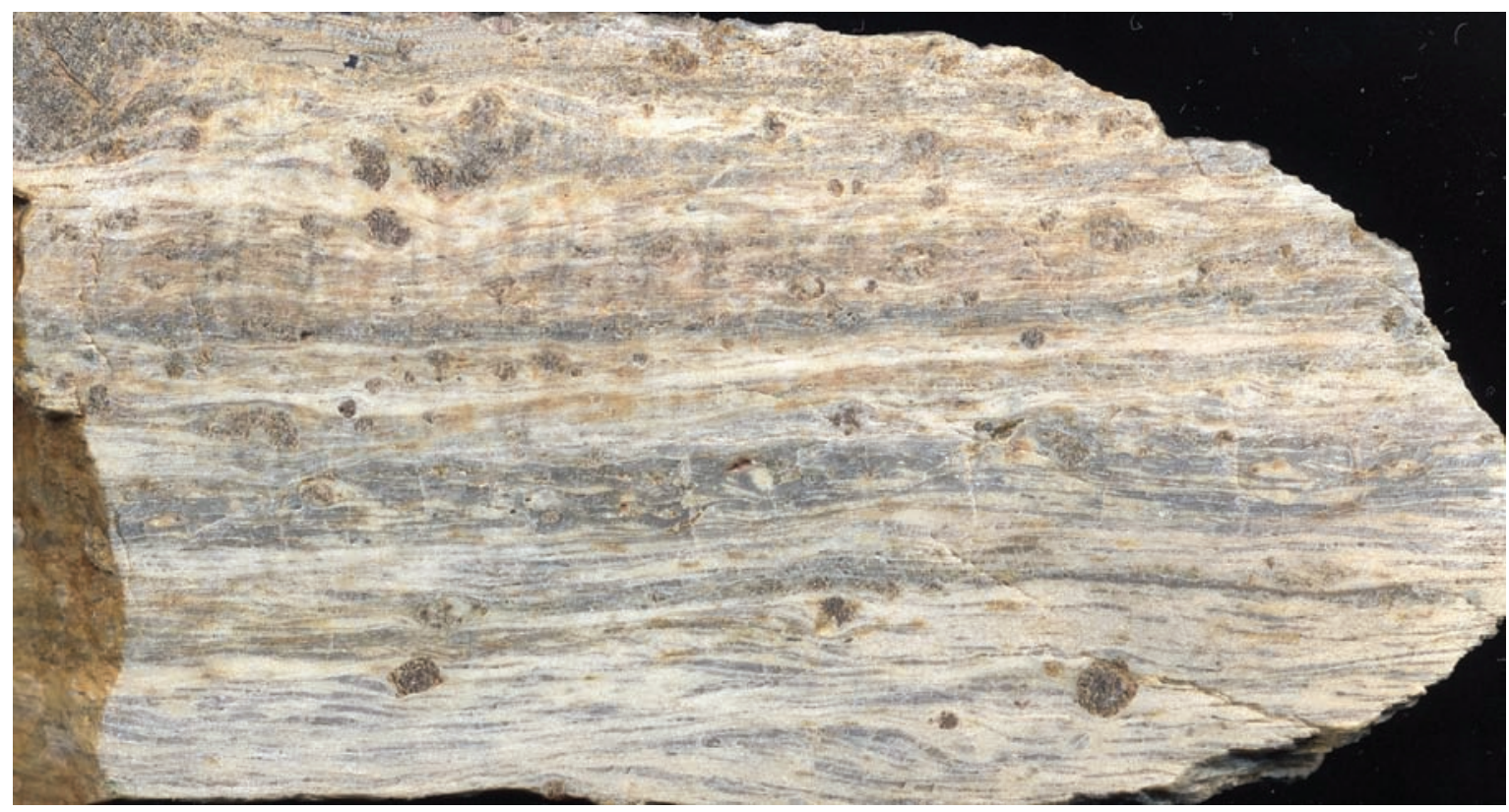

Fig. 7.A cut hand sample of a blastomylonitic diatexite, showing prominent S-C structure (in the lower part), stretching lineation and thin, few millimeters wide banding of mesosomes and granitic leucosomes (one, for example, in the center of the sample). Half way between Kaamanen and Karigasniemi. 
the garnet enderbites. Poikiloblastic garnet has only inclusions and embayments of quartz. Oligoclase occurs with biotite as polycrystalline aggregates between quartz grains. Accessory minerals include orthoclase, zircon, graphite, and some opaque oxides and sulphides.

Garnet granodiorites are relatively rare and are found mostly in those parts of the enderbite association, where crosscutting granitic veins are met with. They are poorly to moderately foliated. Poikiloblastic garnet contains inclusions and embayments of quartz, oxides and biotite. Relatively coarse-grained quartz and orthoclase grains are embedded in a finegrained matrix of oligoclase, biotite, quartz and orthoclase with myrmekitic embayments. Accessory minerals include monazite, zircon, rutile and some graphite, opaque oxides, and sulphides.

\subsection{Anorthosites}

The Angeli massif is partly conformable to the layering of the LGB in the eastern side of the massif and partly fault bounded in the south while in the west it is bordered by the marginal zone of the LGB (Tanaelv belt). The rock is moderately foliated; mediumgrained $(\sim 2 \mathrm{~mm})$ and has a granoblastic texture. Labradorite or bytownite is a major mineral and accessories include hornblende, apatite, ilmenite, rutile \pm garnet \pm scapolite. The smaller bodies are conformable with the metapelite-enderbite sequence although they have sheared margins.

\subsection{Migmatitic metapelites}

The majority of the paragneisses are composed of aluminous, pelitic metatexites and diatexites. In some parts of the LGB, the bedrock consists exclusively of these rocks (for example the hilly highlands east of Saariselkä), while in other areas, metapelites form the country rock for the conformable enderbite-norite series intrusions and their amount may be only half of the total rock volume (Figs. 1 and 2). The contacts towards the enderbites may be sharp but in some cases, the sillimanite-bearing metapelites change to en- derbites via sillimanite-free garnet gneisses and garnet enderbites. In some places, crosscutting intrusive rocks are also found in metapelite bedrock, but these are garnet \pm sillimanite-bearing granites or granodiorites, olivine-diabase veins, and biotite-granites.

The metapelites are always migmatitic. The structure varies from massive to extremely foliated and blastomylonitic. Massive types often have a high neosome/palaeosome ratio and display nebulitic or schlieren structures, while foliated types have lower neosome/palaeosome ratio and are usually more or less stromatic (Figs. 4 and 5). This is especially the case at the NE margin of the belt in the vicinity of Inarijärvi. However, in the other parts of the belt, metapelites are usually foliated and banded S-tectonites or blastomylonites and have a high proportion of neosome (Fig. 6). Due to intensive tectonization, the migmatites are generally transformed into banded gneiss (Figs. 6 and 7). In the NE part of the LGB, the migmatites may contain abundant biotite, being thus darker than in the other parts of the belt.

The palaeosomes (mesosomes) generally have a fine or medium-grained, foliated matrix of quartz, plagioclase (oligoclase or andesine), biotite, sillimanite prisms \pm rutile, ilmenite, and orthoclase. Shear band foliation or schistosity is bent around roundish or flattened garnet porphyroblasts, which range in diameter from few millimeters to several centimeters and contain oriented inclusions of sillimanite, biotite, plagioclase, quartz, ilmenite, and rutile but never orthoclase. Often margins of garnet are slightly replaced by biotite and sillimanite. In other places, especially in the area around Inarijärvi, cordierite may be present. It occurs as matrix grains or small porphyroblasts and has inclusions of biotite, sillimanite, and accessory phases. Margins of garnet porphyroblasts are usually replaced by cordierite in these rocks. Graphite, sulphides, apatite, zircon, and monazite are common accessory phases in palaeosomes. Rarely, hercynite-rich spinel, högbomite, sapphirine, orthopyroxene, kornerupine, or andalusite is found.

The neosomes are divided to melano- and leucosomes. The amount of melanosome is small and they are best visible at the margins of leucosomes in stro- 
matic migmatites in the vicinity of Inarijärvi (Fig. 5). Melanosomes are less abundant in schlieren migmatites and they may be totally lacking especially in the blastomylonitic migmatites. The most probable reason for this is that primary biotite has mostly disappeared and/or the structure is obscured though tectonization; biotite mostly occurs as a back-reaction product around garnets and in shear bands together with sillimanite (Figs. 4 and 6). The melanosomes are usually less than one centimetre wide, well foliated and consist primarily of biotite, prismatic sillimanite, garnet \pm ilmenite, rutile, graphite, and apatite and sometimes cordierite. The grain size is fine or medium with the exception of garnet and cordierite which, when present, occur as porphyroblasts. The inclusions of porphyroblasts are the same as in palaeosomes. Accessory phases may include apatite, zircon, monazite and rarely spinel. Compared to palaeosomes the amount of zircon may be notably high. In some schlieren migmatites, larger, several centimeters wide and irregularly shaped melanosomes are encountered. They occur either associated with palaeosomes or as individual schlieren in leucosomes.

Mineralogically the leucosomes resemble peraluminous granites: The major phases include quartz, plagioclase (oligoclase or less frequently andesine), orthoclase, and garnet. Accessories include zircon, monazite, and occasionally rutile, ilmenite, sillimanite, and biotite. Cordierite and/or andalusite may occur as accessory or major phases, especially in the region near Inarijärvi. The leucosomes are generally medium or coarse-grained, but may also be finer due to mortar or blastomylonitic texture. The rocks often look relatively massive in outcrop, but microscopically they are usually strongly foliated and have elongated rodded quartz grains in a feldspar matrix and/or mono- or polycrystalline $\sigma$-shaped feldspar porphyroclasts in a quartz matrix. Garnet porphyroblasts are usually round in shape and have an even grain size compared to the lens shaped garnets in palaeosomes. They also have orthoclase inclusions in addition to quartz, plagioclase and biotite. Cordierite is often of a deep-blue, jewel-grade variety. Andalusite is rarer and occurs as large, reddish, transparent grains. It is some- times surrounded by micropegmatitic intergrowths of feldspar and quartz. Also sillimanite is found as large prismatic grains up to $5 \mathrm{~cm}$ long. Monazite may be concentrated at the margins of leucosomes as relatively large, $0.5 \mathrm{~mm}$ grains.

\subsection{Silica deficient granulites}

Hackman (1905) proposed the name laanilite for quartz-poor granulite found at Laanila near Saariselkä. Eskola (1952) reconsidered the mineralogy and chemistry of these rocks, which are low in silica and alkalis and extremely rich in aluminium, magnesium and iron. Laanilites occur sporadically within metapelites, are composed of mesosome and leucosome portions and may be considered as a variant of metapelitic migmatite. The mesosomes consist of cordierite, garnet, plagioclase, biotite, quartz, ilmenite, and pyrrhotite. Their texture is crystalloblastic and relatively coarse. Garnet porphyroblasts contain inclusions of sillimanite, biotite, quartz, pyrrhotite and, rarely, plagioclase and spinel. Sillimanite is commonly found as relict inclusion bands in cordierite together with spinel and ilmenite. Other inclusions in cordierite are biotite, garnet, and opaques. Orthopyroxene is found in some samples associated with quartz, garnet, biotite, sillimanite, and cordierite. Zircon, monazite and chalcopyrite are common accessory phases. Andalusite, chlorite and quartz occur in some samples as alteration products of cordierite. The leucosome consist of orthoclase, oligoclase, and cordierite, which may be enclosed or intergrown in poikilitic quartz grains up to 2 $\mathrm{cm}$ large. Garnet grains, up to $1 \mathrm{~cm}$ in diameter, contain inclusions of quartz and less abundant biotite, sillimanite, orthoclase and accessory zircon and monazite. Garnet may be partly replaced by biotite and sillimanite at the margins while orthoclase is replaced by myrmekite. Accessory phases include ilmenite, rutile, pyrrhotite, chalcopyrite, and pyrite.

\subsection{Granite veins}

Granite veins occur locally in the metapelitic rocks. Sometimes they are associated with garnet bearing 
gneissic granodiorites (Fig. 2), but often occur independently in the migmatitic rocks. They crosscut both palaeosome and neosome parts of the rock and seem to be massive, coarse-grained and undeformed in outcrops. However, under the microscope, they are deformed; i.e. quartz shows strong chessboard extinction pattern and orthoclase is granulated in the margins. Potassium feldspar is perthitic orthoclase and up to 1 $\mathrm{cm}$ in size. In some parts of the granulated portions, cross-hatching of microcline is developed. Orthoclase is generally replaced by myrmekite in the margins. Other major phases are biotite and garnet, which is replaced by biotite-oligoclase symplectite and sillimanite prisms in the margins. Accessory phases include graphite, rutile, zircon, monazite, ilmenite, pyrrhotite, and chalcopyrite. Rutile is replaced by ilmenite and, in one sample, rimmed with ilmenite and sillimanite.

\section{Methods}

Microprobe analyses were performed using the JEOL JCXA733 WDS equipped with LINK AN10 automation at the Institute of Electron Optics, University of Oulu. The analytical procedure is described in Muhongo and Tuisku (1996). A few hundred mineral analysis were performed with wide area coverage of the LGB. The cations are calculated according to number of anions in mineral formula.

\section{Mineral chemistry}

In this work we concentrate on the mineral assemblages that are most useful for geological thermobarometry in granulite-facies rocks (Essene, 1989; Harley, 1989) and on the other hand, are most prominent and widespread in the LGB. This allowed us to get regional coverage on the possible change of mineral compositions and to get consistent results on the metamorphic PT regime over the mapped cross sections of the LGB.

\section{I. Garnets}

Garnet analyses are given in Table 1. They are grouped according to the rock type and then sorted by the increasing mole fraction of almandine, which varies from 0.50 to 0.74 . The highest almandine contents were found in metasedimentary biotite-sillimanite gneisses and cordierite-biotite sillimanite gneisses in the NE marginal zone of the LGB as well as in some gneisses in the Archaean Inari terrain and kyanite-biotite gneiss in the $\mathrm{S}$-marginal zone of the LGB. All these samples represent a lower metamorphic grade than the proper metasedimentary granulite, which usually has garnets with almandine contents from 0.50 to 0.64 . The grossular and spessartine contents are low in the metasedimentary granulites, usually $<0.05$ and 0.03 , respectively. In the enderbite series, there is more variation in the garnet composition in the granulite facies proper: the almandine content varies between 0.5 and 0.7 and the grossular fraction may reach 0.16 . The garnets are usually unzoned. Sometimes a very narrow rim was observed, having a higher $\mathrm{Fe} / \mathrm{Mg}$-ratio than the inner parts of the grain.

\subsection{Plagioclase}

Plagioclase analyses are arranged according to the host rock type and increasing anorthite content in Table 2 . In the metasedimentary rocks, the lowest anorthite $(<30 \%)$ and orthoclase ( $<$ the detection limit of $\mathrm{K}_{2} \mathrm{O}$ ) content is encountered in the biotite-sillimanite gneisses of the NE-marginal zone and in the aforementioned kyanite gneiss. Plagioclase with $<\mathrm{An}_{30}$ also occurs in a few cordierite-biotite sillimanite gneisses in the NE marginal zone, but these have a similar Or (1-2\%) than the other migmatitic metapelites. In migmatitic metapelites anorthite content in plagioclase is usually from 30 to $40 \%$. In the enderbite series, there is a higher variation in the plagioclase composition from $\mathrm{An}_{14}$ to $\mathrm{An}_{79}$. No zoning was observed in plagioclase grains.

\subsection{Orthopyroxene}

Orthopyroxene occurs in the enderbitic rocks of the granulite belt proper and amphibolites of the marginal zones and adjoining areas. It is usually hypersthene 


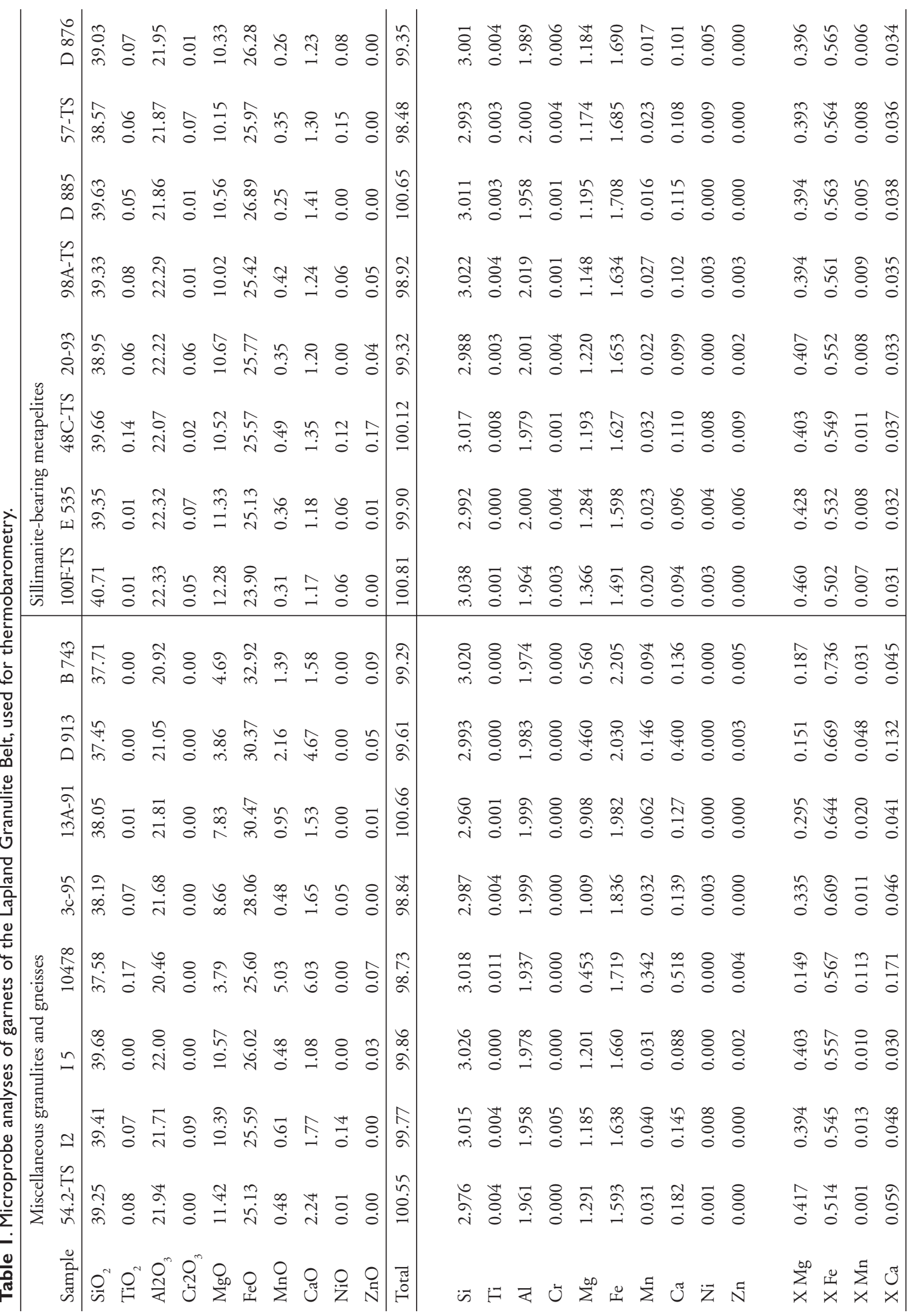




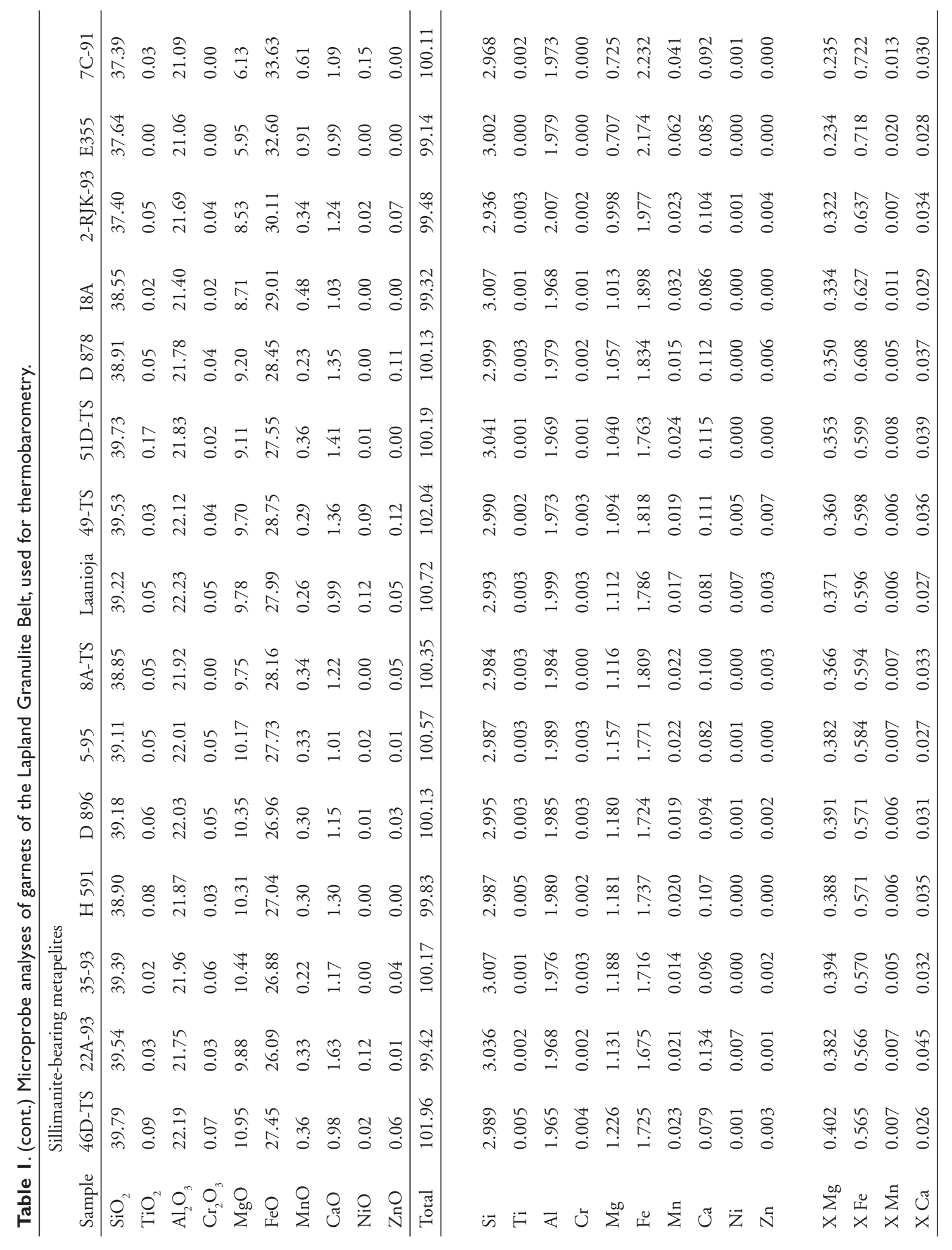




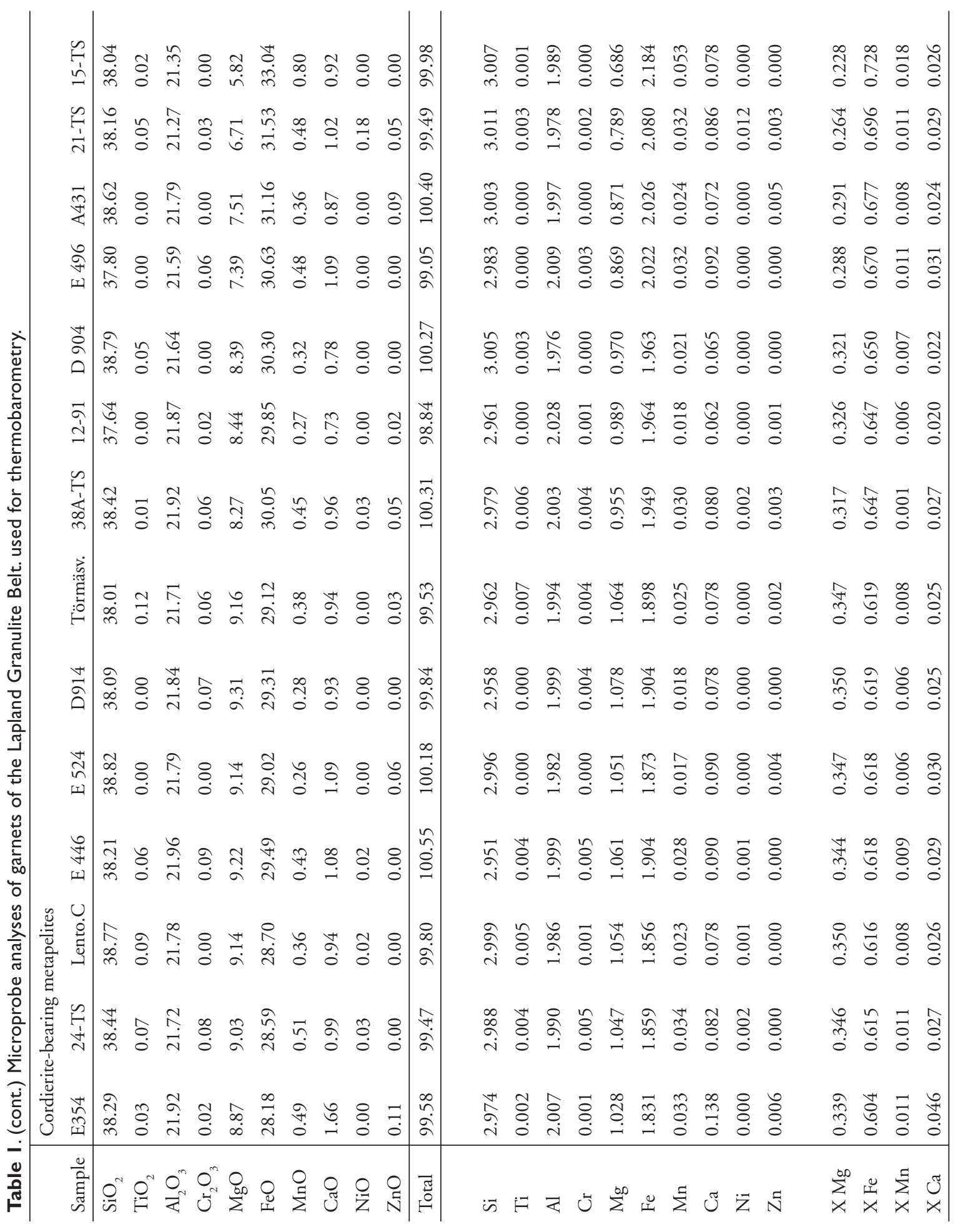




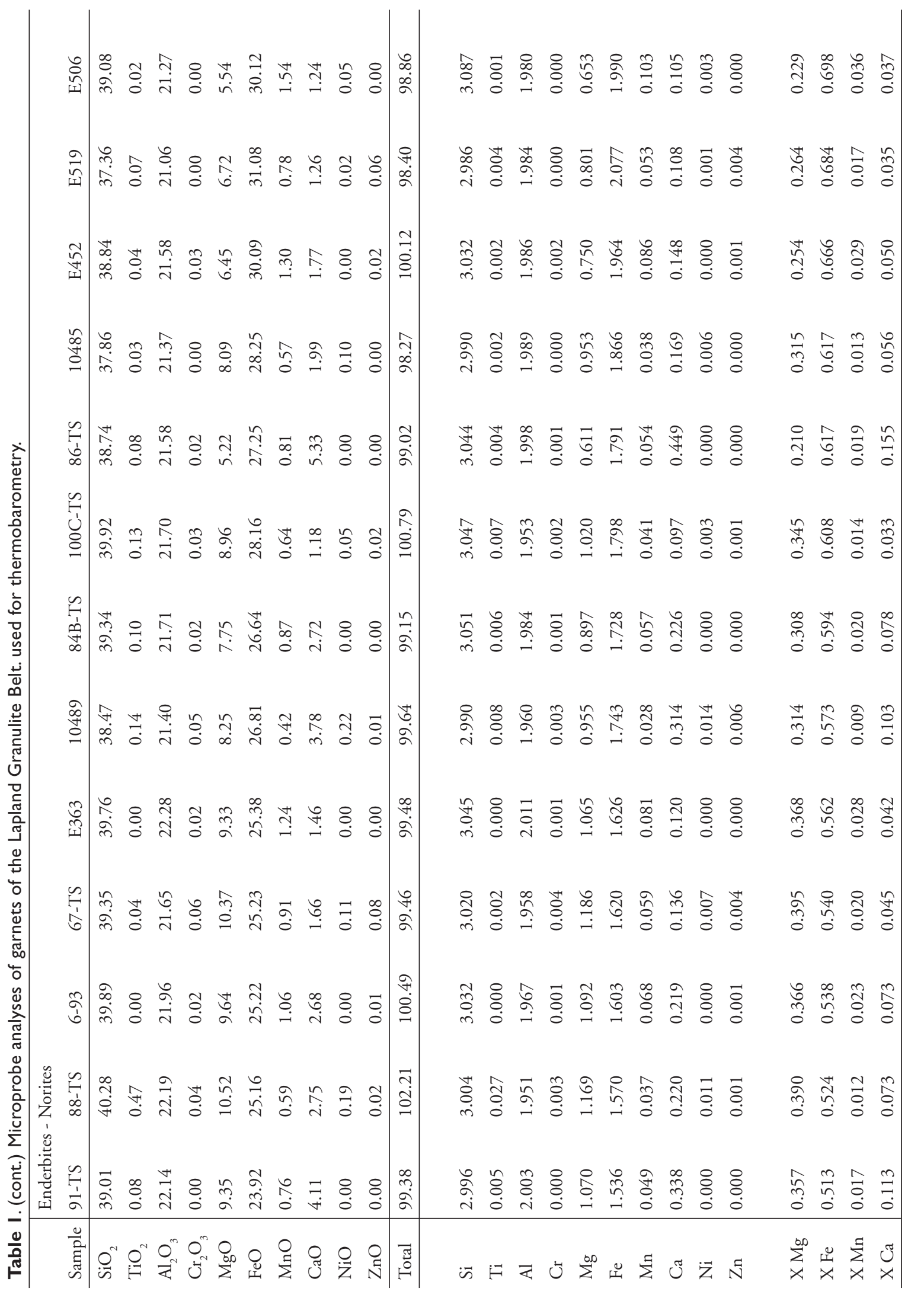




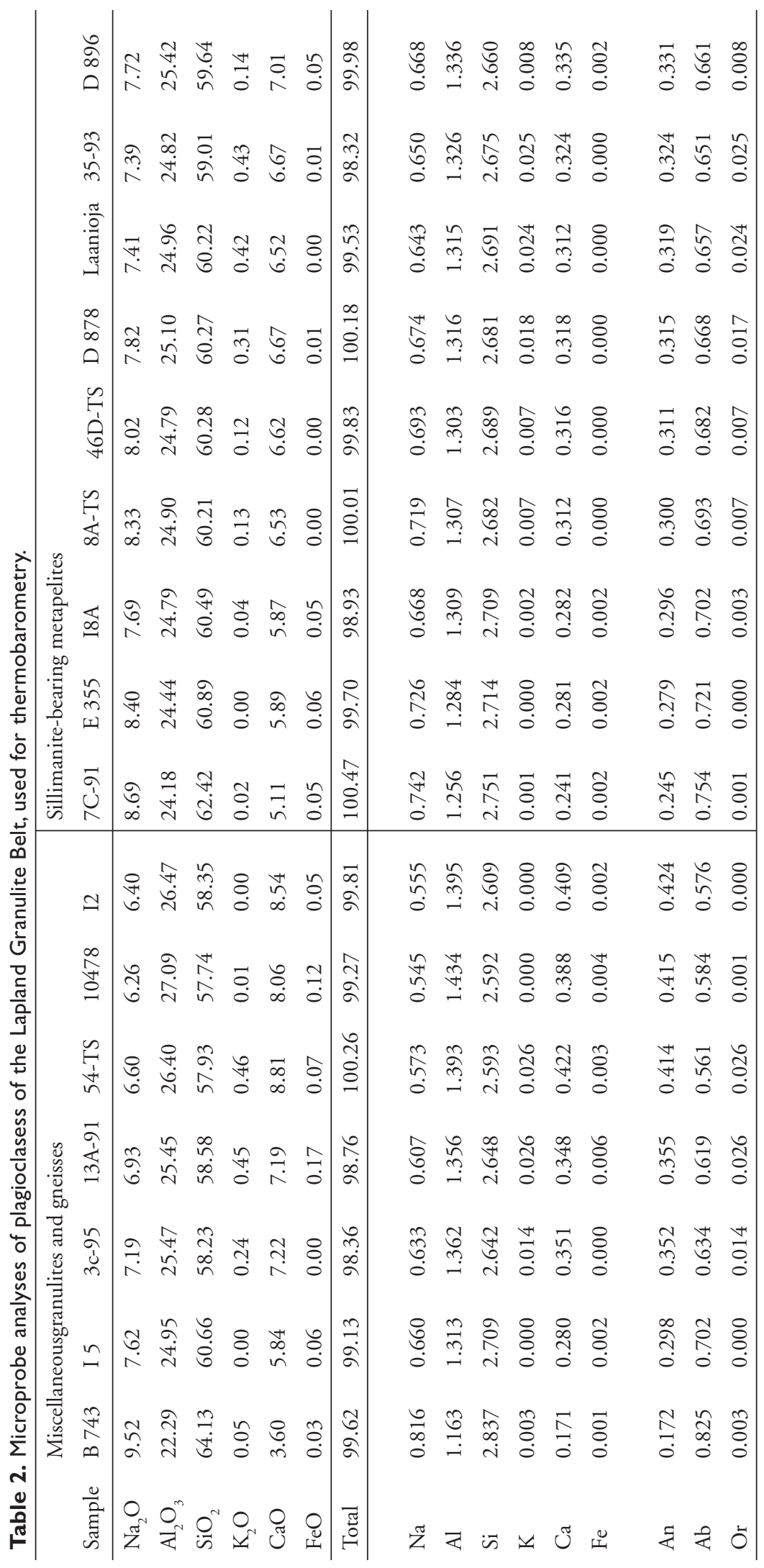




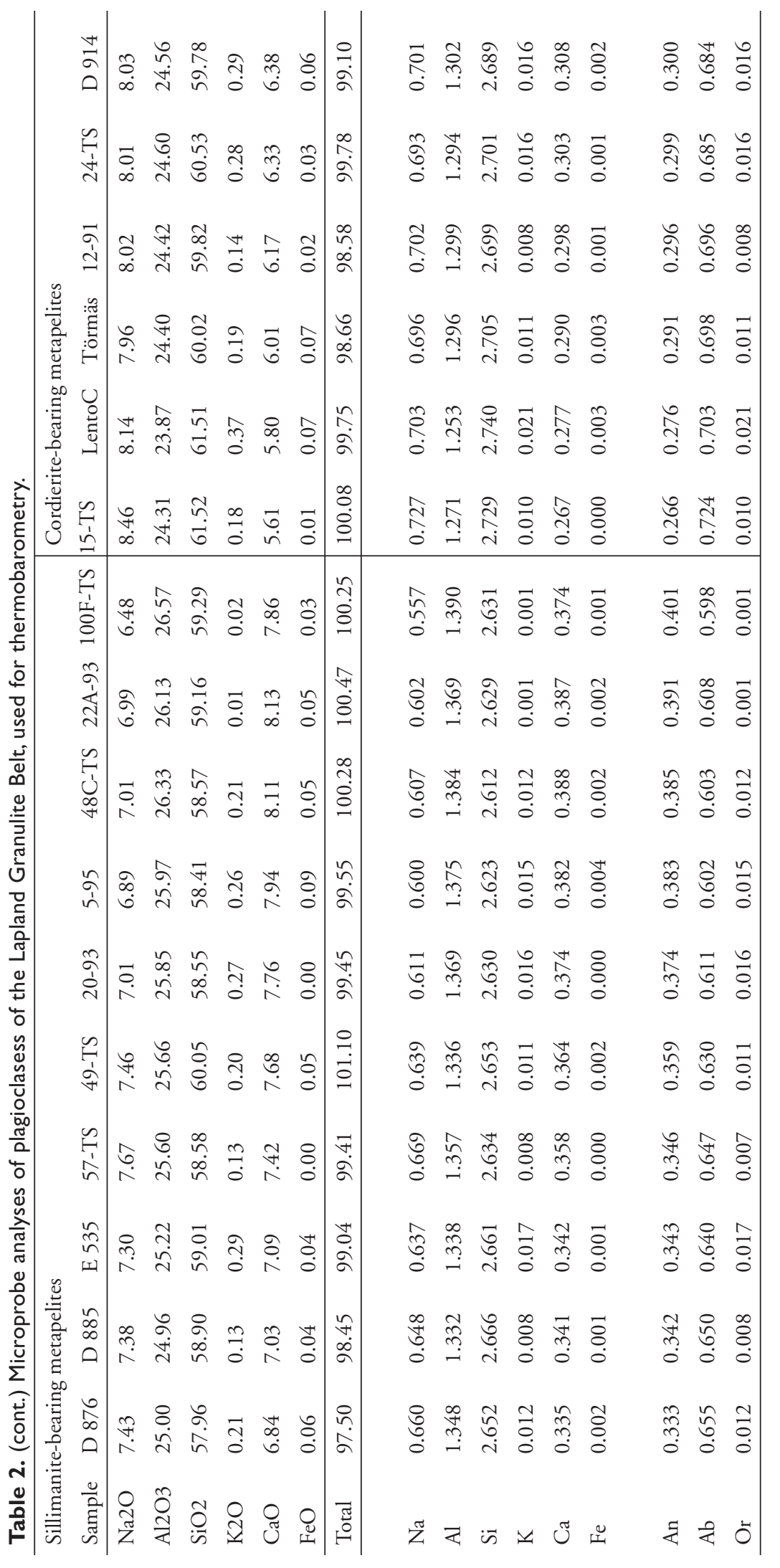




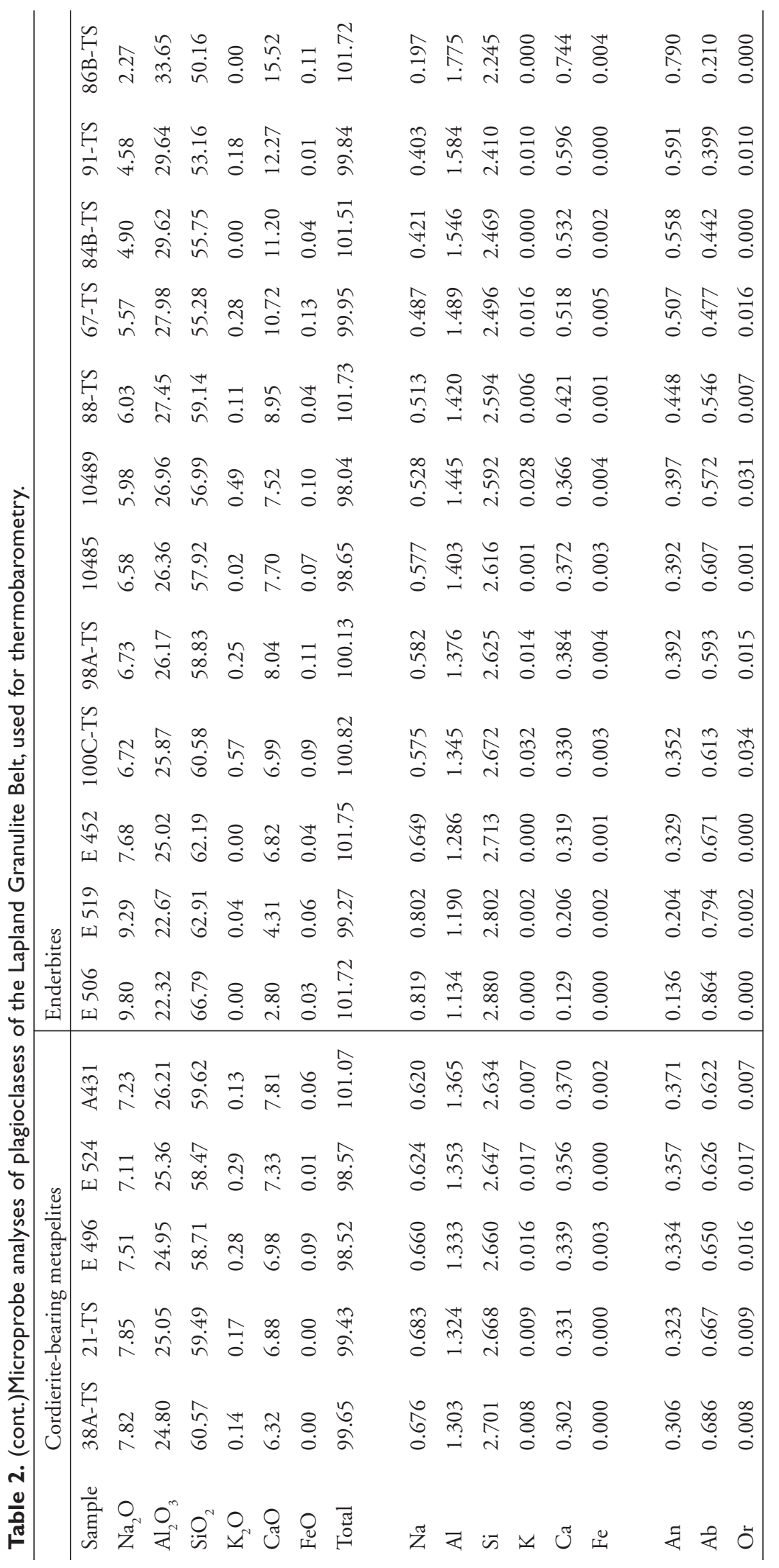




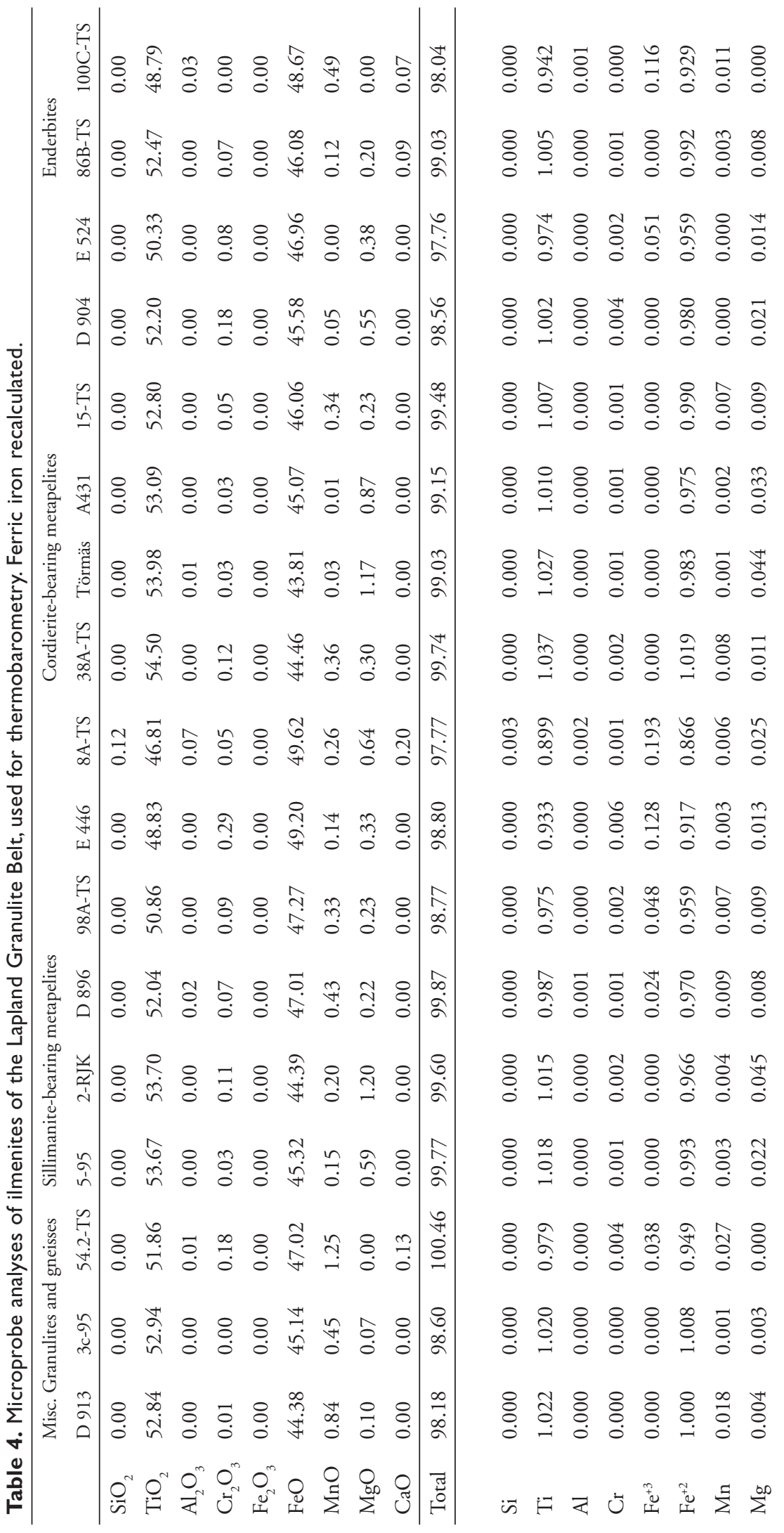


although some ferrohypersthenes were found (Table 3). The range in $\mathrm{X}_{\mathrm{Fe}}$ is from 0.34 to 0.56 . The most iron-rich orthopyroxene was found in a felsic vein in a pyroxene amphibolite of the Inari Terrane. The $\mathrm{Mg} / \mathrm{Fe}$-ratio of orthopyroxene correlates with that in garnet in the garnet-bearing enderbites and is always higher than in the associated garnet. The orthopyroxenes are generally unzoned. Sometimes a very narrow rim was observed, having a lower Fe/Mg-ratio than the inner parts of the grain.

\subsection{Ilmenite}

Representative microprobe analyses of ilmenite are given in Table 4. The calculated ferric iron content is highest in some palaeosomes of the metapelite series rocks and in some garnet-free enderbites. The mole fraction of ilmenite component was usually almost one in most samples and even the lowest values were higher than 0.8 . In one porphyritic orthoclase granite ilmenite contains $15 \%$ of the pyrophanite (Mn) component.

\subsection{Sillimanite and rutile}

Sillimanite was found to be almost pure aluminium silicate. In one sample only the $\mathrm{FeO}$ content was ca. wt. $0.9 \%$. Rutile was also pure. Only a few samples contained less than $0.5 \mathrm{wt} \% \mathrm{FeO}$ or $\mathrm{Cr}_{2} \mathrm{O}_{3}$.

\subsection{Cordierite}

Cordierites were analyzed only from some spinelbearing metapelites (laanilites) in order to calculate the reaction relationships of spinel-forming reactions. $\mathrm{X}_{\mathrm{Mg}}$ was relatively high, ca. 0.8 .

\subsection{Spinel}

Spinel was analyzed, together with cordierite and garnet, to reveal its reaction relationship in metapelites. The composition of spinel is degenerate with that of garnet and sillimanite. The hercynite content is ca. 66 $\%$. In addition to hercynite and $\mathrm{Mg}$-spinel, the spi- nel contains ca. $3 \%$ of the gahnite and $1 \%$ chromite component.

\section{Key metamorphic equilibria and features}

Excluding the innermost cores of some garnet grains, biotite and sillimanite are abundant inclusions in garnet in metapelites (Fig. 8a, c and d). This is true both in the marginal zone of the LGB in the NE where biotite and sillimanite occur as a stable matrix assemblage, and in granulites proper, where either sillimanite or biotite is absent in the matrix. These inclusions may be used to demonstrate the prograde reaction history of the LGB. It is most probable that sillimanite was the first aluminium silicate generated because not a single grain of other polymorphs was found within the garnet. The first possible reaction to produce an aluminium silicate in the sillimanite field is

(1) Staurolite + chlorite + muscovite + quartz $=$ biotite + aluminium silicate (sillimanite) $+\mathrm{H}_{2} \mathrm{O}$

This reaction is further supported by numerous sillimanite and biotite inclusion in garnet, suggesting that these phases were abundant before and during the growth of majority of the garnet. The major part of garnet was then most probably produced by reaction

(2) Staurolite + muscovite + quartz $=$ garnet + sillimanite + biotite $+\mathrm{H}_{2} \mathrm{O}$

This reaction produced the common marginal zone assemblage, which, in addition to garnet porphyroblasts or poikiloblasts, exclusively contains abundant and relatively coarse-grained biotite and sillimanite in the matrix. The fate of muscovite is unclear but if any remained in reaction (2), it probably then disappeared during the succeeding migmatization by the reaction

(3) Muscovite + plagioclase + quartz $=$ liquid $+\mathrm{K}$ feldspar + sillimanite 
a)

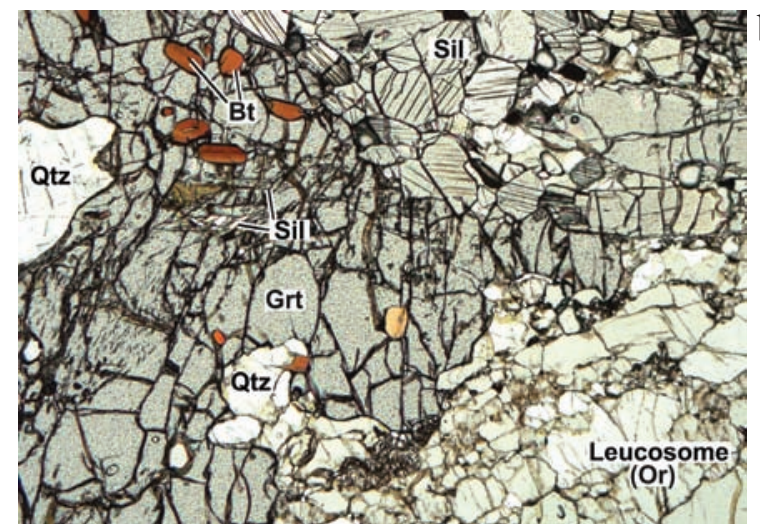

c)

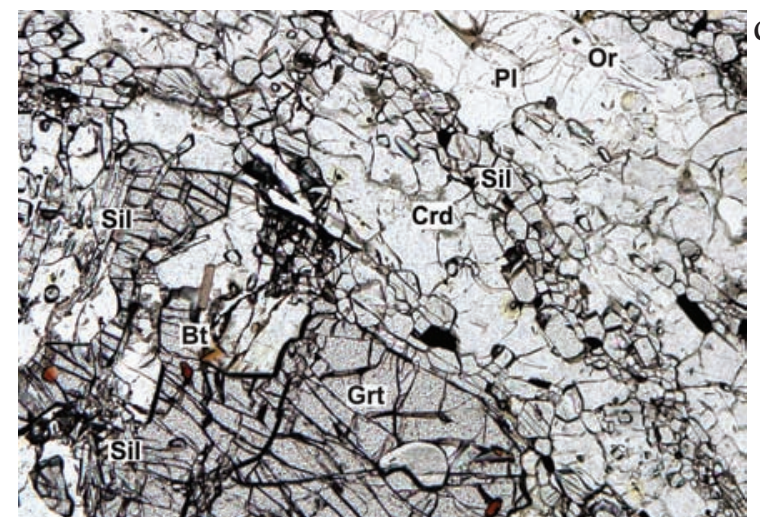

e)

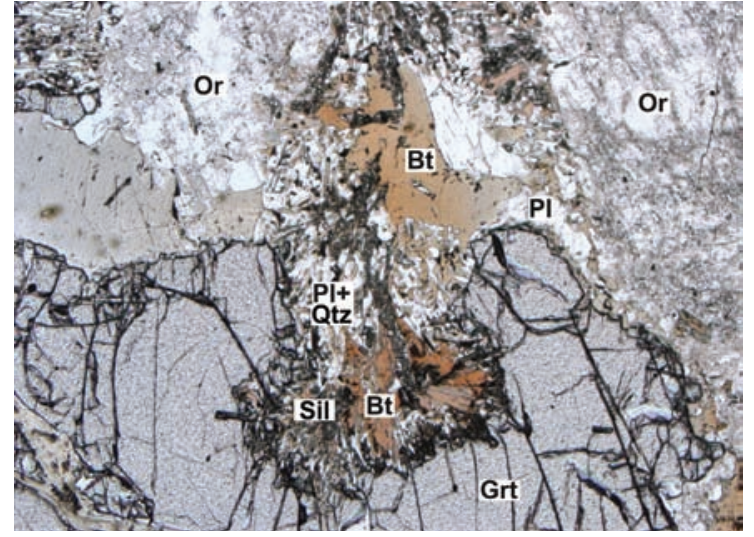

b)

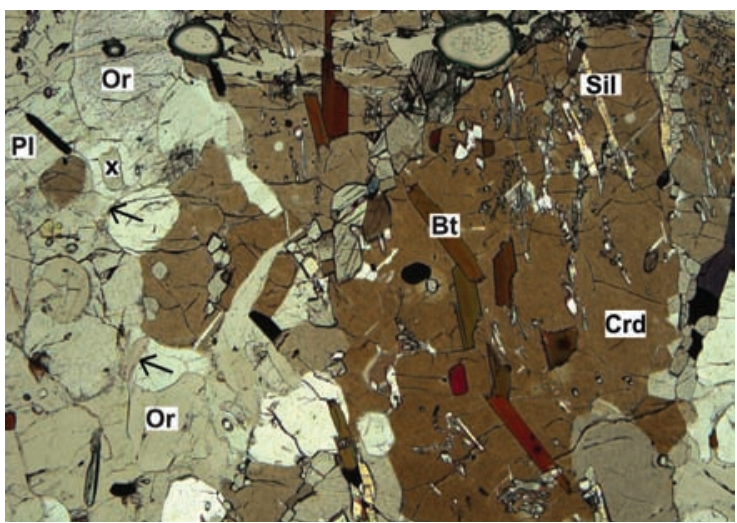

d)

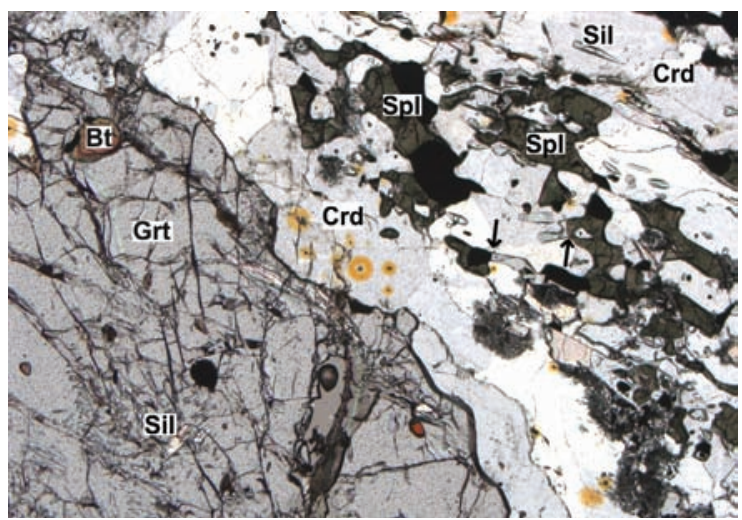

f)

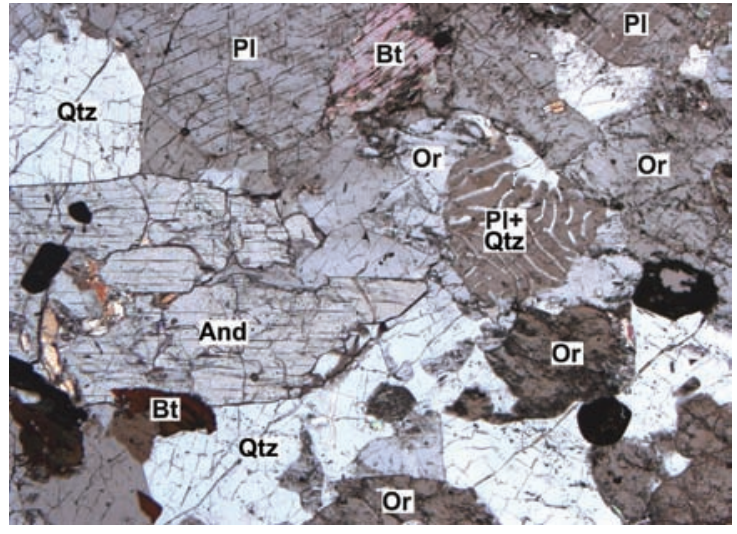

Fig. 8. Photomicrographs of granulite samples and their reaction textures. All figures are $3 \mathrm{~mm}$ wide. a) Relic, abundant sillimanite and biotite inclusions in a garnet porphyroblast which lies in biotite free, sillimanite rich rock matrix. This is cut by orthoclase rich leucosome, indicating different stages of biotite dehydration reaction (4). b) Reaction textures related to biotite dehydration melting reaction (5): Relic, abundant sillimanite and biotite inclusion in a cordierite porphyroblast which lies in biotite free rock matrix with abundant orthoclase, sillimanite and garnet porphyroblasts (not in Figure). Arrows indicate places where interstitial orthoclase replaces plagioclase. c) Textures indicating both heating i.e. dehydration melting of biotite (reactions 4 and 5) and decompression reaction (7): Biotite and sillimanite inclusions in a garnet porphyroblast which is in turn replaced by a reaction rim composed of cordierite. Plagioclase of the matrix is replaced by a large, interstitial orthoclase grain in the upper right corner. d) Textures indicating both dehydration melting of biotite (4 and 5) and reaction (I3): Biotite and sillimanite inclusions in a garnet porphyroblast which is in turn replaced by a reaction rim composed of cordierite. Prismatic sillimanite of the matrix is replaced by spinel (shown by arrows). e) and f) cooling stage, retrogressive reactions. e) reverse of reaction (4) producing sillimanite-biotite-plagioclase-quartz sympectite in the expence of orthoclase and garnet and f) granitic leucosome where large andalusite grains have crystallized with simultaneous formation of plagioclase-quartz symplectite (myrmeckite). Some biotite is formed together with andalusite. 

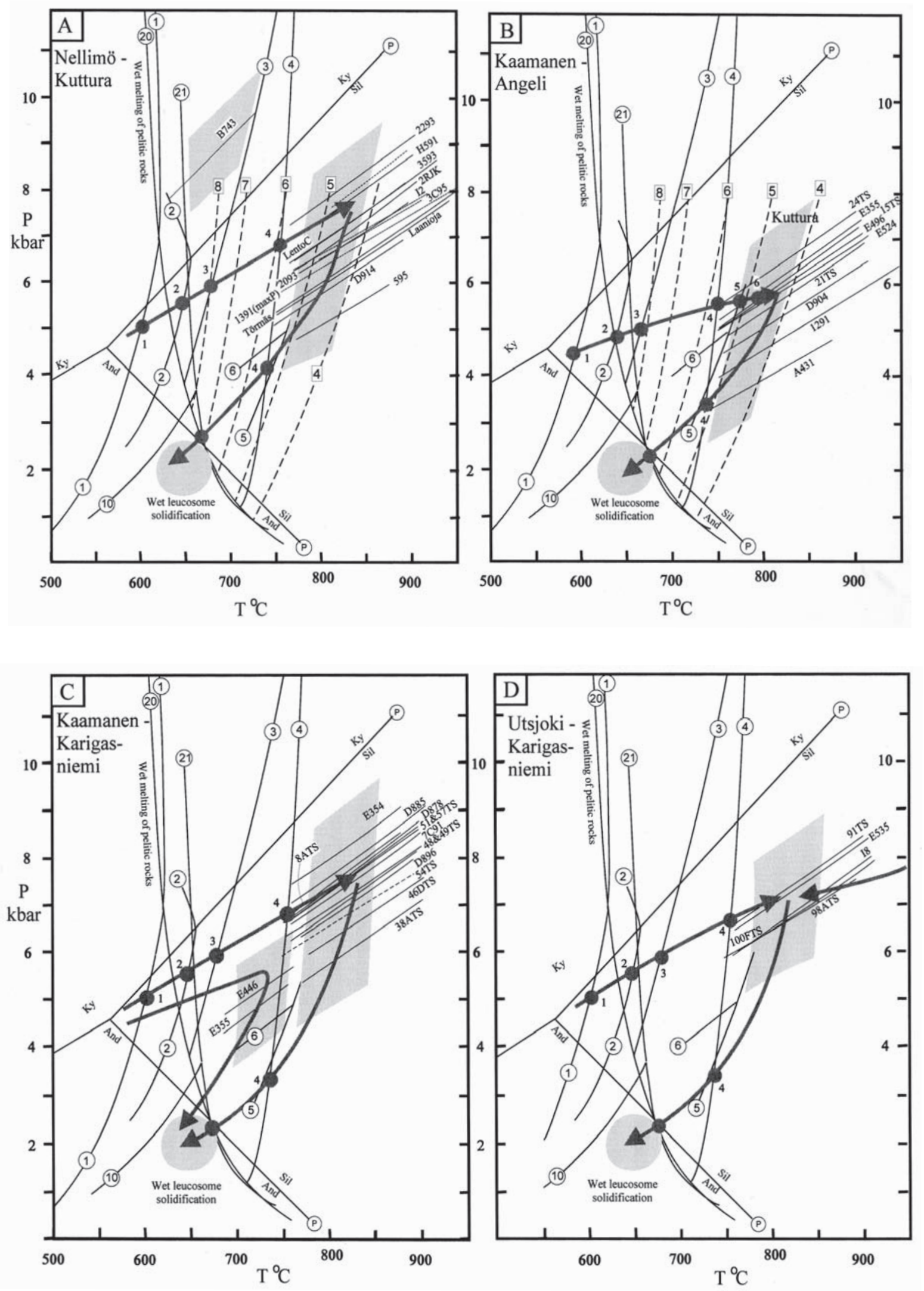
Excluding some outcrops, which have at least two leucosome phases, there is little evidence for reaction (3) and the most extensive migmatization was produced by the following reactions (Fig. 8a, b and c):

(4) Biotite + sillimanite + plagioclase + quartz $=$ liquid + K-feldspar + garnet

(5) Biotite + sillimanite + plagioclase + quartz $=$ liquid + K-feldspar + garnet + cordierite

(6) Biotite + sillimanite + plagioclase + quartz $=$ liquid + K-feldspar + cordierite

All metapelites in the LGB show evidence for some of these reactions. In the NE marginal zone, the reactions did not progress to the end (Fig. 5) and both biotite and sillimanite are abundant in palaeosomes. In the granulite belt proper, the palaeosomes always lack either biotite or sillimanite, indicating the completion of the reactions (Fig. 6) and relatively higher temperature during the peak of metamorphism. The temperature difference and continuous nature of the melting reactions is also reflected in the mineral compositions as the marginal zone metapelites have the highest almandine content in garnet and the highest albite and lowest orthoclase content in plagioclase.
Which of the reactions (4) to (6) takes place depends both on the pressure of metamorphism and rock composition. Reaction (4) predominates at higher pressures and in rocks with higher Fe/Mg ratios (see the review in Thomson, 2001). In some outcrops of the NE marginal zone, the rock composition varies so much, probably due to original bedding of the metasediment, that all reactions have taken place in different parts of the rock producing either garnet, garnet and cordierite or cordierite-bearing assemblages. Cordierite, however, is usually found only in the NE part and NE marginal zone of the LGB, which means that a relatively high pressure prevailed during the dehydration melting.

In cordierite-bearing migmatites, the garnet-bearing assemblage is regularly replaced by cordierite and additional orthoclase has grown. This is revealed by cordierite and orthoclase-bearing reaction rims around the garnet. Apparently this occurred due to decompression during the melting by a continuous reaction (Fig. 8c):

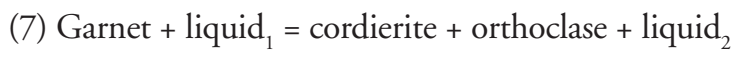

The reactions discussed above are represented in Fig. 9, except that reaction (7) is omitted for clarity. Also divariant fields of reactions (4) to (6) are omitted, while only the onset of the reactions is shown. The minimum temperature achieved in the NE mar-

Fig. 9. Results of thermobarometry and petrogenetic (grid) criteria to define conditions of metamorphism of metagreywackes throughout the LGB. See text for detailed discussion on thermobarometry and each profile presented in Figs. 9a-d. Sources of reaction curves (circled symbols) are following: (I) St+Chl = Bt+Als after Spear (1993); (2) $\mathrm{St}=\mathrm{Bt}+$ Als + Grt after Pattison \& Tracy (199I); (3) dehydration melting of muscovite after Pëto (1976); (4) beginning of dehydration melting of biotite to form L+Kfs $+\mathrm{Grt}$ after Le Breton and Thompson (1988); (5) dehydration melting of biotite to form $\mathrm{L}+\mathrm{Kfs}+\mathrm{Grt}+\mathrm{Crd}$ as wel as (10) Ms+Qtz = Kfs+Als $+\mathrm{V}$ after Pattison \& Tracy (199I); (20) wet melting of pelitic rocks after Thompson (1982); (2I) wet melting of Ms+PI+Qtz after Tuttle \& Bowen (I958); (P) aluminium silicate stability after Pattison \& Tracy ( 1991$)$; dotted curves numbered by squared 4 to 8 indicate liquidus curves for granitic magma with equivalent $\mathrm{H}_{2} \mathrm{O}$ content after Holtz et al. (200I). Grey arrows indicate average PTpaths for the profiles and it should be noted, that e.g. in Nellimö-Kuttura profile the NE part underwent relatively lower pressure path as the average was. Dots on the arrows indicate reactions, which probably took place during the evolution of the LGB, and the numbers besides them correspond to the reactions in the text. Grey quadrilaterals give average maximum PT-conditions with error of about I kbar in P and grey circles give retrograde conditions of the profiles. Note that the pressure constraints for reaction points $\mathrm{I}-4$ in the figures are poor and pressure is only limited by the presence of sillimanite during reactions 2 and 4 . 
ginal zone, necessary for the beginning of dehydration melting of biotite, is ca. $750^{\circ} \mathrm{C}$. All the reactions from (4) to (7) may be onset and will be promoted by decompression in a temperature range of $720-760{ }^{\circ} \mathrm{C}$.

The first signs of cooling are given by granitic migmatite leucosomes and some larger peraluminous crosscutting granites, which most probably were generated by melt segregation from pelitic migmatites. Garnets in these rocks are regularly more or less replaced by a mixture of biotite and sillimanite or biotite-sillimanite-quartz symplectite (Fig. 8e), which are produced by the reverse of reaction (4). Textures indicating reverse reactions (5) and (6) also occur but are less common. This might suggest that cooling took place with considerable decompression and the PT path had a similar slope to that of the reaction curves of (5) and (6). Another indication of decompression of garnetiferous granite bodies is the replacement of rutile and garnet by ilmenite and sillimanite by the reaction:

(8) Garnet + rutile = ilmenite + sillimanite + quartz

The most important evidence of lowered pressure (during cooling) is given by generation of andalusite, which is encountered in two contexts. First, it is found within pseudomorphs after cordierite by the reaction:

(9) Cordierite $=$ andalusite + chlorite + quartz

However, this is common only in the NE parts of the LGB, where cordierite is present. Regionally more important is crystallization of andalusite in granitic leucosomes and in some larger granitic pods. Andalusite may occur as large crystals up to several centimeters long and most probably crystallized from a melt, because no replacement textures were found. This kind of andalusite is most common in the NE part of the LGB, but is also found in the most SW part, for example in sample I1.1 from Kuttura, used for dating in Part II of this contribution (Fig. 8f). Because andalusite apparently crystallized together with K-feldspar and quartz, the final crystallization of these portions of granites and leucosomes took place below the wet melting temperature of granitic rocks and beneath the pressure of the reaction curve:

(10) Muscovite + quartz $=$ K-feldspar + aluminium silicate + vapor

Corresponding reactions are presented in Fig. 9. The pressure was below 3 or $2 \mathrm{kbar}$ and temperature ca. $650^{\circ} \mathrm{C}$, depending on which aluminium silicate phase diagram is accepted.

Some assemblages and reactions involving spinel in laanilites and less commonly migmatitic metapelites need a special attention, although these do not have regional extent. The metapelite sample I5 from Kaarle Kustaa shaft consists of quartz, plagioclase, garnet, biotite, rutile, and interstitial orthoclase probably representing melt extraction. Garnet contains inclusions of biotite and it seems clear that melting reaction (4) took place in the rock. Besides, there are narrow bands of garnet and sillimanite, not in contact with quartz. Both sillimanite and garnet have nucleus of spinel and sporadic inclusions of quartz. Evidently, a reverse of the reaction

(11) Garnet + sillimanite $=$ spinel + quartz

took place in the bands. Because the equilibrium conditions were on the right side, the maximum temperature exceeded ca. $900-950^{\circ} \mathrm{C}$ at a pressure of at least $6.5 \mathrm{kbar}$, according to petrogenetic grids of Dasgupta et al. (1995) and Sengupta et al. (1991, 1999; see also other references therein). The intermediate pressure is also supported by the presence of rutile and lack of ilmenite and cordierite.

Migmatitic laanilites near the NE marginal zone, near the sampling site E496 (Fig. 1) contain assemblages of 1) garnet-cordierite-quartz-orthopyroxeneplagioclase, with relics of sillimanite and spinel and 2) garnet-cordierite-spinel-plagioclase, with relics of sillimanite and quartz. In both types, abundant sillimanite and biotite inclusions in garnet suggest that an early melting reaction (4) or more probably (5) took place. The latter assemblage (Fig. 8d) may then 
Table 5. Result of thermobarometry

\begin{tabular}{|c|c|c|c|c|c|c|c|c|c|c|}
\hline \multirow[b]{2}{*}{ Profile } & & & & & & & \multicolumn{4}{|c|}{ GAES + GAFS + Grt-Opx } \\
\hline & Sample & $\begin{array}{c}\text { P kbar } \\
\text { (GASP) }\end{array}$ & s & $\begin{array}{c}\mathrm{T}^{\circ} \mathrm{C} \text { used in } \\
\text { GASP and } \\
\text { GRISP }\end{array}$ & $\begin{array}{c}\text { P kbar } \\
\text { (GRISP) }\end{array}$ & $s$ & P kbar & s & $\mathrm{T}^{\circ} \mathrm{C}$ & s \\
\hline \multirow{15}{*}{ Nellimö - Kuttura } & D914 & 6.1 & 0.9 & 825 & & & \multirow{15}{*}{8.2} & \multirow{15}{*}{1.1} & \multirow{15}{*}{856} & \multirow{15}{*}{77} \\
\hline & 1391 & $6.6(\max )^{*}$ & 1.0 & 825 & & & & & & \\
\hline & 595 & 5.4 & 1.0 & 825 & & & & & & \\
\hline & Törmäs & 6.4 & 0.9 & 825 & & & & & & \\
\hline & 3C95 & & & 825 & 6.9 & 1.0 & & & & \\
\hline & LentoC & 7.3 & 1.0 & 825 & & & & & & \\
\hline & Laanioja & 6.3 & 1.0 & 825 & & & & & & \\
\hline & H591 & 7.8 & 1.0 & 825 & & & & & & \\
\hline & 3593 & 7.3 & 1.0 & 825 & & & & & & \\
\hline & 693 & & & & & & & & & \\
\hline & 2093 & 6.8 & 1.0 & 825 & & & & & & \\
\hline & 2293 & 8.2 & 1.0 & 825 & & & & & & \\
\hline & 2RJK & 7.1 & 1.0 & 825 & & & & & & \\
\hline & $\mathrm{I} 2$ & & & 825 & 7.0 & 1.0 & & & & \\
\hline & B743 & 9.2 & 1.0 & 700 & & & & & & \\
\hline \multirow[t]{9}{*}{ Kaamanen - Angeli } & E355 & 6.2 & 0.9 & 825 & & & & & & \\
\hline & E524 & 5.9 & 0.9 & 825 & & & & & & \\
\hline & E496 & 6.0 & 0.9 & 825 & & & & & & \\
\hline & D904 & 5.3 & 0.9 & 825 & & & & & & \\
\hline & A431 & 4.2 & 1.0 & 825 & & & & & & \\
\hline & 1291 & 4.9 & 0.9 & 825 & & & & & & \\
\hline & $15 \mathrm{TS}$ & 6.1 & 0.9 & 825 & & & & & & \\
\hline & $21 \mathrm{TS}$ & 5.7 & 0.9 & 825 & & & & & & \\
\hline & $24 \mathrm{TS}$ & 6.6 & 1.0 & 825 & & & & & & \\
\hline \multirow[t]{16}{*}{ Kaamanen - Karigasniemi } & 7C91 & 6.5 & 1.0 & 750 & & & & & & \\
\hline & $\mathrm{E} 452$ & & & & & & 4.7 & 1.1 & 648 & 72 \\
\hline & E363 & & & & & & 6.6 & 1.1 & 752 & 75 \\
\hline & E354 & 8.3 & 1.0 & 825 & & & & & & \\
\hline & E446 & 5.5 & 1.0 & 750 & & & & & & \\
\hline & 8TS & 7.4 & 1.0 & 800 & & & & & & \\
\hline & $38 \mathrm{TS}$ & 6.0 & 1.0 & 825 & & & & & & \\
\hline & D896 & 7.0 & 1.0 & 825 & & & & & & \\
\hline & 46TS & 6.5 & 0.9 & 825 & & & & & & \\
\hline & 48TS & 7.2 & 1.0 & 825 & & & & & & \\
\hline & 49TS & 7.3 & 1.0 & 825 & & & & & & \\
\hline & $51 \mathrm{TS}$ & 7.6 & 1.0 & 825 & & & & & & \\
\hline & $54 \mathrm{TS}$ & & & 825 & 6.8 & 0.9 & & & & \\
\hline & 57TS & 7.6 & 1.0 & 825 & & & & & & \\
\hline & D878 & 7.8 & 1.0 & 825 & & & & & & \\
\hline & D885 & 8.0 & 1.0 & 825 & & & & & & \\
\hline \multirow[t]{17}{*}{ Utsjoki - Karigasniemi } & 10478 core & & & & & & 7.1 & 1.1 & 740 & 66 \\
\hline & E591rim & & & & & & 4.6 & 1.1 & 584 & 69 \\
\hline & E519core & & & & & & 5.9 & 1.1 & 692 & 73 \\
\hline & E506 & & & & & & 7.4 & 1.1 & 679 & 65 \\
\hline & I8 & 6.8 & 1.0 & 825 & & & & & & \\
\hline & E535 & 7.3 & 0.8 & 825 & & & & & & \\
\hline & 91TS & 7.4 & 0.8 & 825 & & & & & & \\
\hline & 98ATS & 6.7 & 0.9 & 825 & & & & & & \\
\hline & 67TS & & & & & & 7.4 & 1.1 & 976 & 93 \\
\hline & 10485rim & & & & & & 6.7 & 1.0 & 804 & 80 \\
\hline & 10485 core & & & & & & 8.0 & 1.1 & 931 & 83 \\
\hline & 100CTS & & & & & & 5.2 & 1.1 & 734 & 85 \\
\hline & 100FTS & 6.6 & 0.9 & & & & & & & \\
\hline & 84BTS & & & & & & 8.1 & 1.1 & 942 & 87 \\
\hline & 86BTS & & & & & & 7.1 & 1.0 & 760 & 83 \\
\hline & 10489 & & & & & & 8.6 & 1.1 & 788 & 72 \\
\hline & 88DTS & & & & & & 8.7 & 1.1 & 798 & 77 \\
\hline
\end{tabular}

${ }^{*}$ Rutile absent, max $\mathrm{P}$ assuming rutile present 


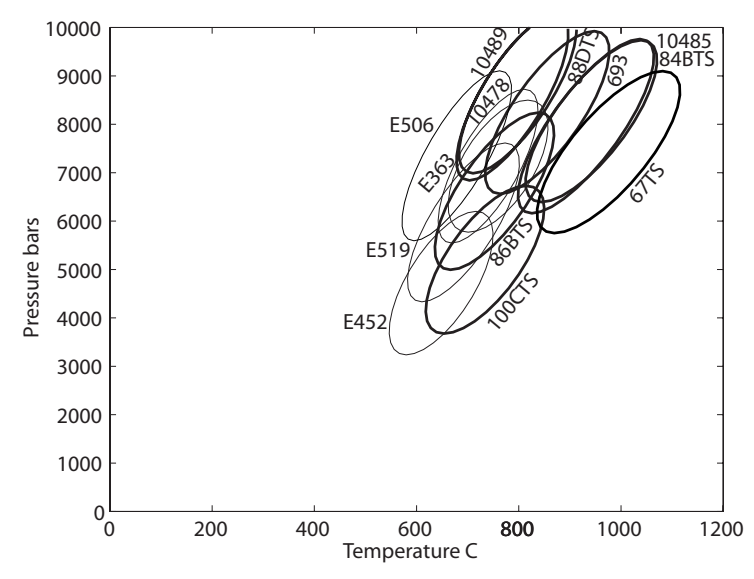

Fig. 10. Results of thermobarometry to define conditions of metamorphism of garnet-bearing rocks of the norite-enderbite series of the LGB. Calculated error is shown by the eclipses. See text for detailed discussion.

have developed by the continuous reactions

(12) Garnet + sillimanite + quartz $=$ cordierite and, after consumption of quartz,

(13) Garnet + sillimanite $=$ cordierite + spinel

or, if the temperature of reaction (11) was exceeded and sillimanite consumed, by the continuous reaction

(14) Garnet + spinel + quartz $=$ cordierite

The former assemblage (garnet-cordierite-orthopyroxene-quartz-plagioclase) may have developed by univariant reaction (11) followed by a reaction (14) and then, after consumption of spinel, by continuous reaction

(15) Garnet + quartz = cordierite + orthopyroxene

The development of both assemblages suggests a relatively high temperature of ca. $900^{\circ} \mathrm{C}$ and a relatively low pressure below $6 \mathrm{kbar}$. All the continuous reactions (12) to (15) considered above are highly pressure-dependent and favor decompression. The reaction scheme is supported, in addition to textural features, by the degenerate composition of garnet, spinel, and sillimanite.

The enderbite-norite series lacks prominent progressive reaction textures. Neither does orthopyroxene or garnet have inclusions of preceding lower-grade minerals. This means, that no progressive metamorphic evolution may be constructed for these rocks. Contrary, for example orthopyroxene may contain abundant exolutions of clinopyroxene, which suggests cooling from a very high temperature. Retrogressive textures are common as is partial replacement of orthopyroxene by biotite or biotite-quartz symplectite. This indicates cooling by the reverse of the reaction

(16) Biotite + quartz $=$ orthopyroxene + orthocla se + fluid

As orthoclase is rare in the enderbite series, this reaction may imply some metasomatic inflow of potassium (together with fluid). Alternatively, potassium was derived from the orthoclase component of the ternary feldspar solid solution. In the garnet-bearing enderbites, garnet is often more or less replaced by plagioclase and orthopyroxene by the reaction

(17) Garnet + quartz $=$ orthopyroxene + plagioclase

most probably having taken place during decompression of the LGB.

Some assemblages and reactions in the rocks from the marginal zone, outside the granulite belt proper, have important petrogenetic and tectonic consequences. A relatively high pressure-temperature-gradient during the metamorphism of the SW marginal zone is indicated by the assemblage kyanite-garnet-biotite-muscovite-plagioclase-quartz. It indicates that the breakdown temperature of staurolite was exceeded but the dehydration melting temperature of muscovite was not reached in the kyanite field, i.e. pressure was at least $7 \mathrm{kbar}$ and the temperature $650-700{ }^{\circ} \mathrm{C}$. From the same zone, Tuisku and Makkonen (1999) found metamorphosed ma- 
fic rocks with the assemblage olivine-orthopyroxeneclinopyroxene-pargasite-spinel giving metamorphic conditions of ca. $11-12 \mathrm{kbar}$ and $670^{\circ} \mathrm{C}$. A relatively high $\mathrm{P} / \mathrm{T}$ ratio is also indicated by the common occurrence of garnet-bearing diopside amphibolites in the SW marginal zone, while decompression is demonstrated by a development of plagioclase rim around garnet by the reaction

(18) Garnet + quartz $=$ clinopyroxene + anorthite

The plagioclase rims may be strongly elongated parallel to the NNE dipping stretching lineation of the amphibolites which indicates that the decompression took place prior to or during SSW-directed thrusting of the LGB. Garnet amphibolites are also found in the NE marginal zone, where orthopyroxene-plagioclasesymplectite was developed between clinopyroxene and garnet during decompression by the reaction

(19) Garnet + clinopyroxene +quartz = orthopyroxene + plagioclase

In summary, according to the mineral assemblages and reaction textures described above, metapelites of the granulite belt proper show evidence for progressive heating in intermediate pressure conditions at least up to $750^{\circ} \mathrm{C}$ and prominent dehydration melting and migmatization. Locally, the temperature may have exceeded $900^{\circ} \mathrm{C}$, while the marginal areas of the LGB underwent only partial dehydration melting. The progressive stage was followed by decompression to ca. 2-3 kbar and cooling. In contrast, enderbites do not show evidence of progressive heating but decompression and cooling is obvious. Marginal zones of the LGB were metamorphosed at lower temperatures of ca. $650-700^{\circ} \mathrm{C}$ with a higher $\mathrm{P} / \mathrm{T}$ ratio than the granulite belt proper. Post-peak decompression and cooling is obvious also in the marginal zone.

\section{Thermobarometry}

The mineral assemblage garnet-plagioclase-sillimanite-quartz occurs in the palaeosomes of the metapelites throughout the LGB and thus allows the GASP (garnet-aluminium silicate-silica-plagioclase) barometer to be applied over a regional extent. Another useful barometer is GRIPS (garnet-rutile-ilmenite-plagioclase-silica) because either rutile or ilmenite or both usually occur in the palaeosomes of garnet-bearing metapelites. Even if ilmenite is absent, this barometer may be used to calculate the minimum possible pressure and in the absence of rutile, a maximum possible pressure is obtained, because both phases are almost pure when they occur in the LGB. The latter may also be applied to the garnet-bearing enderbites, which usually contain ilmenite, thus giving a maximum possible pressure. Also, it may be used to receive reference data from adjacent tonalites gneisses outside the LGB proper. The third useful set of thermo-barometers is found in the enderbite series where the garnet-orthopyroxene-plagioclase-quartz assemblage is relatively common and has a similarly wide regional extent to the metapelite assemblages. Both the GAFS and GAES barometers (garnet-anorthite-ferrosilite/ enstatite-silica) and garnet-orthopyroxene Fe/Mg exchange thermometers were used in this study.

Calculations were made using numerous published calibrations of the aforementioned thermobarometers, but to maintain consistency in the calculation and to allow readers to receive a picture of the regional variation in the metamorphic conditions in the LGB, we concentrate here on reporting results obtained by the Berman thermodynamic data set and TWEEQU software (Berman, 1988; 1991; and June/92 update). The error calculation was made by INVQ method and software (Gordon, 1992; Gordon et al., 1994; Ghent \& Gordon, 2000). Both core and rim composition of the minerals was used in calculations. Rims always gave a little lower $\mathrm{T}\left(-20-50^{\circ} \mathrm{C}\right)$ and P ( $-0.2-0.5 \mathrm{kbar})$ than the cores. Summary of results is given in Table 5 where samples are grouped according to mapped cross-section of the LGB and arranged from $\mathrm{E}$ to $\mathrm{W}$ or from NE to SW within each of the profiles (Fig. 1) to illustrate across-thebelt variation in the metamorphic conditions. Results from cores in metagreywackes are given in Figures 9a-d. Each of the Figures represents results of 
one cross-section of the LGB to illustrate the alongstrike variation in the metamorphic conditions. They also show some important reference equilibria of metapelitic rocks discussed above. The continuous contours mark the results from GASP barometry and long dashed the GRISP barometry. The sample numbers referring to the localities shown in Fig. 1 are given with each contour. Results calculated by combination of the GAES and GAFS barometers and garnetorthopyroxene thermometer are given in Figure 10. Most of these results are from the fourth, Utsjoki-Karigasniemi profile.

The easternmost profile extends from Nellimö at the Russian border to ca. $110 \mathrm{~km} \mathrm{SW}$ at Kuttura. The results are shown in Fig. 9a, including also some scattered samples east of the profile. The rocks are migmatitic metapelites and therefore the isopleths are shown above the dehydration melting temperature of biotite and sillimanite. The calculated pressure varies from ca. 5-6 kbar at the NE to ca. $8 \mathrm{kbar}$ at the SW. Tectonic slicing of the LGB during thrusting and uplift after the peak of metamorphism most probably cause some exceptions from the systematic pressure increase. Sample B743 from the SW marginal zone is included for reference. The rock is garnet-kyanite gneiss with abundant biotite and muscovite and hence the isopleth is drawn between the reaction contours bordering the stability field of the muscoviteplagioclase-biotite-kyanite-garnet-quartz assemblage either in hydrous or dry conditions. Sample 693 in Figure 10 is a garnet-bearing enderbite from the SWpart of the profile and the result of calculation is in a good agreement with those obtained from the metapelites in this area.

The next section is from the central part of the LGB. It extends from Kaamanen, situated to the north of Inarijärvi, $70 \mathrm{~km}$ west to Angeli at the Norwegian border. The results are presented in Fig. $9 \mathrm{~b}$. Again, the dehydration melting temperature of biotite constrains the low temperature limit of isopleths. The calculated pressures are considerably lower than in the Nellimö-Kuttura profile. The lower pressure (about 4-6 kbar) is also supported by the fact that no garnet-bearing enderbites were found in this profile. Comparison with the metamorphic conditions of enderbites is thus not possible here. The lowermost pressure was calculated for sample A431, which is a sample from the Lake Möyssäjärvi area, between this and the previous profile, which may represent an even lower pressure part of the LGB. The calculated low pressures are supported by the fact that all samples, except E355 which is from the higher-pressure part of the array, contain abundant cordierite.

The third profile begins in the area of the marginal zone, east of Kaamanen, with more abundant biotitesillimanite gneisses and diopside amphibolites mixed with migmatitic metapelites. It extends $80 \mathrm{~km} \mathrm{NW}$ across the LGB to Karigasniemi on the western side of the belt. The results are shown in Fig. 9c. The GASPisopleths of samples E355 and E446 representing the migmatitic biotite-sillimanite gneiss area east of Kaamanen are drawn to cross-cut the dehydration-melting curve while the GASP-isopleths of the rest of the samples are drawn on the high-T side of it. The garnetorthopyroxene thermobarometry of enderbite samples E452 and E363 from the biotite-sillimanite gneiss area support the lower average temperature east of Kaamanen. The calculated pressures increase towards the NW part of the profile and near Karigasniemi they are as high as in the Kuttura area of the fist profile.

The fourth section represents the northernmost part of the LGB. It begins at Utsjoki in the eastern margin of the belt and ends $30 \mathrm{~km}$ north of Karigasniemi at the western margin of the belt. The GASP assemblages show completion of the dehydration reaction (4) and calculated pressures are similar to those in the first and third profile (Fig. 9d). Garnet-bearing enderbites are abundant in this section, which suggests a relatively high pressure/temperature ratio. The results of garnet-orthopyroxene thermobarometry confirm this but also show considerable scatter in the PT-space and P/T-ratio (Fig. 10). This can be explained by the palaeotectonic position. For example, samples E506, 10489 and 88TS, which have the highest $\mathrm{P} / \mathrm{T}$ ratio, similar to that of sample $\mathrm{B} 743$ from the first section, are situated next to the basement and probably represent the lowermost part of the belt during granulite metamorphism. The same is seen in the 
series of samples 100CTS, 100FTS, 84BTS, 86BTS, 88 TS and 10489, which show quasi-systematic increase in the P/T ratio and absolute pressure (Table5). The series most probably represents a single tectonic unit from roof to floor. The pressure difference of 3.5 kbar corresponds to a difference of more than $10 \mathrm{~km}$ in the crustal load during metamorphism, which is also the thickness of the unit measured in the field.

The difference of the present data from that of the earlier works (Hörmann et al., 1980; Raith \& Raase, 1986; Barbey \& Raith, 1990; Perchuck et al., 2000) is that there is greater aerial coverage, four profiles are studied instead of one and the profiles are more continuous. According to our data it seems that there is more variation in the PT regime and the across-belt change of metamorphic conditions is not as systematic as earlier interpreted. It also appears that alongstike variation in metamorphic conditions is considerable. Our PT data support the suggestion of Korja et al. (1996) that the LGB consists of several structural units, which were juxtaposed after the peak of the regional metamorphism.

\section{Discussion}

\section{I. Evolution of the metasedimentary sequence of the $L G B$}

The progressive heating path of the metasedimentary rocks of the Lapland granulite belt can be determined from the petrological data (Fig. 9.). Abundant biotite and sillimanite inclusions in garnet throughout the belt indicate that biotite-sillimanite-garnet gneiss was a prevailing rock type during heating from reaction isograd (2) to (4). Bt-Sil-Grt gneisses were generated by reaction (2) at $620-650^{\circ} \mathrm{C}$ and 3.6-6.5 kbar from staurolite-bearing micas schists or gneisses. Bt-Sil-Grt gneisses still exist in some lower grade areas in the marginal zones, especially in NE part of the LGB, often mixed with migmatitic granulite, indicating that maximum temperature was here near the reaction isograd (4) at about $750^{\circ} \mathrm{C}$. However these conditions are exceeded in the major part of the LGB, as shown by regional completion of reaction (4). Also results of thermo barometry suggest that this temperature was exceeded in a regional scale.

Mineral assemblages, as well as thermobarometry indicate, that there was considerable regional as well as local variation in pressure from about 5 to $9 \mathrm{kbar}$ during the peak of metamorphism, which is shown in Figures 9a-d. This may be explained by variation in depth. Considering the present $35 \mathrm{~km}$ maximum thickness of the LGB the lithostatic pressure difference of $12 \mathrm{kbar}$ could have been possible. This is, however, not observed and it may be concluded that the present day structure of the LGB is a result of tectonic duplexing after the peak of metamorphism, as proposed already by Korja et al. (1996). Observed pressure variation indicates that maximum difference of lithostatic load between the lower and upper parts of the LGB was about $12 \mathrm{~km}$ (compare with Fig. 4 in Korja \& al., 1996). In the present day cross-sections, sudden upward jumps in calculated pressures occur, as for example between samples 100CTS and 10489 in Utsjoki-Karigasniemi profile. This feature together with a shear zone observed between these sampling sites is in accordance with the post-peak duplexing and thus strongly supports the model presented in Korja et al. (1996; Fig. 5).

The retrograde part of the PT evolution of the LGB metapelite is governed by decompression and cooling, which is shown by the numerous reaction textures and low-pressure assemblages in the leucosomes, especially those where orthoclase occurs in equilibrium with andalusite. PT paths are given in Figures $9 \mathrm{a}-\mathrm{d}$ for each sub-area of the LGB. Cooling from ca. $850^{\circ} \mathrm{C}$ to less than $650^{\circ} \mathrm{C}$ and decompression from 5-9 to as low as $2 \mathrm{kbar}$ is recorded. It is apparent, that leucosomes were not completely crystallized until the end of decompression. On the other hand, pressure differences (i.e. load) between various parts of the LGB was considerably reduced at the end of decompression. This suggests that the decompression and duplexing took place simultaneously by crustal scale thrusting as proposed by Korja et al. (1996). 


\subsection{Evolution of the norite-enderbite series}

Already Hörman et al. (1980), and later Barbey and Raith (1990) proposed that the LGB igneous series evolved in a convergent volcanic arc setting. The primitive mantle-normalized trace element spectrum of the norite-enderbite series has similarities to recent subduction-related mafic and intermediate arc volcanics (e.g. Shinjo et al., 2000; Churikova et al., 2001; Jolly et al., 2001; Hochstaedter et $\mathrm{al}, 2001)$. In particular the peaks of $\mathrm{Rb}, \mathrm{Ba}, \mathrm{K}$, and $\mathrm{Sr}$, observed in the LGB, are considered to indicate a subduction-related extra component in the spectrum (Pearce, 1983) while the relative even depletion of $\mathrm{Nb}$, $\mathrm{Ta}$ and $\mathrm{Ti}$ might indicate removal of these components to the mantle due to a refractory eclogitic slab (MacDonough, 1991). The latter is considered one of the strongest pieces of evidence for subduction-related magmatism even in palaeoigneous rocks (Leybourne et al., 1999). Also, the negative anomalies at $\mathrm{Zr}$ and Th observed in the LGB are common in subduction environment magmatism (Pearce, 1983; Jolly et al., 2001). It is thus evident that a volcanic arc existed between the Karelian province, now in the south and southwest, and the Kola Province including the Inari Terrane, now in the northeast of the LGB.

If we take into an account the great volume of the igneous rocks in the LGB, one of the major reasons of high-grade metamorphism of the metapelites in the LGB could have been heat liberated from cooling and crystallization of arc magmas.

Thermobarometry, mineral chemistry, textural and field data suggest that the pressure was high during the intrusion of norites and enderbites into the metasedimentary rocks. On the other hand, it seems that the metapelites were remarkably heated during the burial because sillimanite, not kyanite, is the prevailing prograde aluminium silicate (Fig. 9).

As described in the section of the key reactions, all visible reaction textures in enderbites and norites were generated due to decompression and cooling. In contrast, metapelites show abundant progressive reaction textures in addition to cooling and decompression textures. Because the thermobarometry gives similar PT-conditions both for metasediments and metaigneous rocks, and the minerals are homogeneous in the metaigneous rocks, the norite-enderbite series evidently crystallized within the same conditions where metapelites suffered the maximum temperature of metamorphism. This is also supported by field data, as igneous rocks form flat, sill-like and deformed bodies sandwiched between metapelite layers and often show assimilated contacts and degree of mixing with the metapelites. Chilled margins were not observed. Evidently, the igneous series subsequently shared the evolution with the metapelites, cooling and decompressing together with them.

\subsection{SW Marginal zone}

Metamorphic pressure and temperature may also be determined for the marginal zones, especially the southwestern footwall zone. Tuisku and Makkonen (1998) calculated $11-12 \mathrm{kbar}$ and $670^{\circ} \mathrm{C}$ for the Vaulo mafic-ultramafic complex and 8.2-9.8 kbar and $650-720^{\circ} \mathrm{C}$ is calculated for Korvatunturi area in this work (sample B743 in Fig. 9a). These data is in accordance with the southwest-directed thrusting model of the LGB presented in many papers (Marker, 1988; Barbey and Raith, 1990; Korja et al., 1996 and Tuisku and Makkonen, 1998).

\subsection{Evolution of migmatitic granulite complexes}

Lapland granulite belt is significant migmatitic granulite belt which has common features with many other granulite terrains, such as a high temperature/pressure ratio and a clockwise PT path. Our study has shown that the LGB has much greater amount of intrusive rocks than previously thought. Arc related magmas apparently were an important heat source for metamorphism of the LGB. It is possible, that collision related magmatism could be predominant heat source also in other granulite belts rich in metasedimentary rock, regardless of the exposure of the igne- 


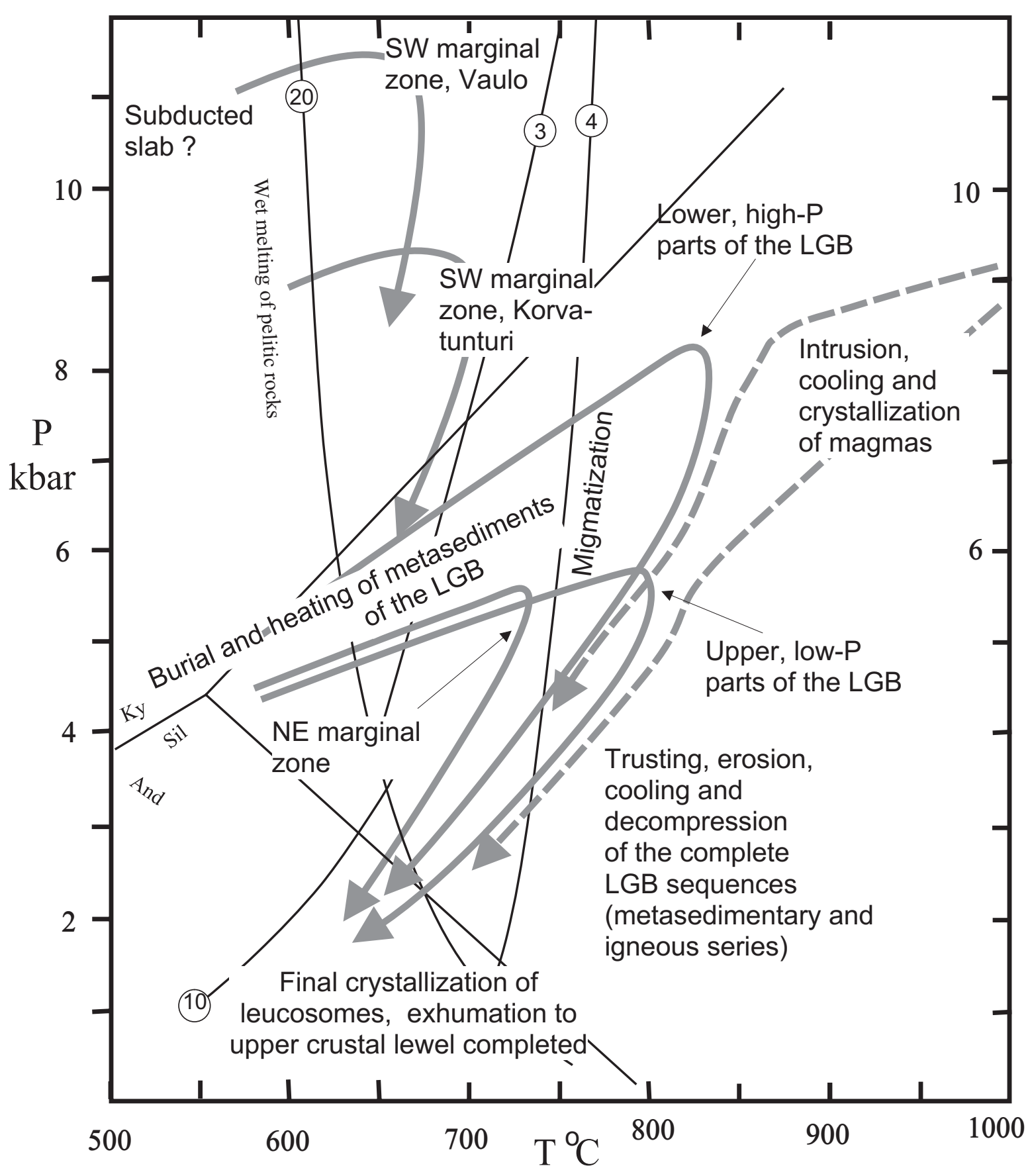

Fig. II. Summary of the PT evolution of the LGB, including evolution of different parts of the LGB proper as well as the marginal zones. The evolution of the supracrustal rocks of the LGB as well as the evolution of marginal zone assemblages are given in continuos grey arrows while the evolution of norite-enderbite series is given by dashed arrows. Most important petrogenetic and tectonic stages are indicated by text. 
ous rocks. The homogeneous composition of minerals in rock samples of the LGB evidently is a result of relatively long residence in high temperature conditions. Cooling rate of the migmatites was probably slow because of the heat of crystallization and cooling of the intrusions was transported to the metasedimentary units in the beginning of the uplift. Even during the uplift the cooling was somewhat delayed which is shown by well developed decompression textures, then followed by cooling related retrograde textures, and, a very high T/P-ratio in the end of leucosome crystallization. The temperature still was ca. $650^{\circ} \mathrm{C}$ in this stage but the pressure only ca. $2 \mathrm{kbar}$, corresponding to a lithostatic load of only $6-7 \mathrm{~km}$. Evidently; the heat of crystallization of abundant leucosomes greatly affected to the late stage evolution of the LGB, and this surely is the case in other granulite belts with high amount of migmatitic rocks (Brown, 2002).

\section{Conclusion}

The first published, complete PT paths of the Lapland granulite belt are presented in Fig 9. Moreover, this is done in regional scale covering most of the LGB and also some marginal areas. The results are schematically summarized in Fig. 11 together with some important petrogenetic data and tectonic interpretation.

The metapelites were heated in sillimanite field at about $5 \pm 1$ kbar pressure. Mineral assemblages and thermo barometry determine the peak metamorphic conditions, viz. $-850^{\circ} \mathrm{C}$ and $5-9 \mathrm{kbar}$ in this migmatite forming stage Norite-enderbite series, arc type magmas were intruded in the buried metapelite sequence and their crystallization and cooling probably was an important heat source for the metamorphism of the metasediments. After the crystallization of magmas, the metamorphic maximum and partial melting stage of metasediments, both rock series apparently shared a common cooling and decompression path. This was caused by southwest directed thrusting of the complete rock sequence and rapid erosion of the uplifted thrust sheets. The crystal- lization of the leucosomes of migmatitic metapelites took finally place at $-650^{\circ} \mathrm{C}$ and $2-3 \mathrm{kbar}$, at the end of thrusting and exhumation stage of the LGB. Our data have also important constraints on the evolution of other decompressing granulite belts. Crystallization of melts and cooling of the rocks unquestionably takes time; especially if mantle derived melts are important heat sources of the metamorphism but also the heat of crystallization of the leucosomes greatly affects the late evolution.

\section{Acknowledgements}

We are grateful to Eero Hanski for suggestions that greatly improved the first version of the manuscript. Financial support by Finnish Cultural Foundation (A. E. Nordenskiöld fund) is greatly acknowledged. The journal reviewers Dr. Stefan Bergman and Dr. Pentti Hölttä are greatly acknowledged especially for proposals that made the illustrations and metamorphic reaction sequence more understandable.

\section{References}

Barbey, P. \& Raith, M., 1990. The granulite belt of Lapland. In: Vielzeuf, D. \& Vidal, Ph. (eds.) Granulites and crustal evolution. Kluwer Academic Publishers, Dortrecht, p. 111-132.

Barbey, P., Bernard-Griffiths, J. \& Convert, J., 1986. The Lapland charnockitic complex: REE geochemistry and petrogenesis. Lithos 19, 95-111.

Berman, R.G. 1988. Internally-consistent thermodynamic data for stoichiometric minerals in the system $\mathrm{Na}_{2} \mathrm{O}$ $\mathrm{K}_{2} \mathrm{O}-\mathrm{CaO}-\mathrm{MgO}-\mathrm{FeO}-\mathrm{Fe}_{2} \mathrm{O}_{3}-\mathrm{Al}_{2} \mathrm{O}_{3}-\mathrm{SiO}_{2}-\mathrm{TiO}_{2}$ - $\mathrm{H}_{2} \mathrm{O}-\mathrm{CO}_{2}$. Journal Petrology 29, 445-522.

Berman, R.G. 1991. Thermobarometry using multiequilibrium calculations: a new technique with petrologic applications. Canadian Mineralogist 29, 833-855.

Bernard-Griffiths, J., Peucat, J.J., Postaire, B., Vidal, P., Convert, J. \& Moreau, B., 1984. Isotopic data (U-Pb,Rb-Sr, $\mathrm{Pb}-\mathrm{Pb}$ and $\mathrm{Sm}-\mathrm{Nd}$ ) of the mafic granulites from Finnish Lapland. Precambrian Research 23, 325-348.

Braathen, A. \& Davidsen, B., 2000. Structure and stratigraphy of the Palaeoproterozoic Karasjok Greenstone Belt, North Norway - regional implications. Norsk Geologisk Tidsskrift 80, 33-50.

Bridgwater, D., Autrheim, H., Hansen, B.T., Mengel, F., Pedersen, S. \& Winter, J., 1990. The Proterozoic Nagssugtoqidian mobile belt of southeast Greenland: A link between the eastern Canadian and Baltic shields. Geoscience Canada 17, 305-310.

Brown, M., 2002. Retrograde processes in migmatites and 
granulites revisited. Jounal of Metamorphic Geology 20, 25-40.

Churikova, T., Dorendorf, F. \& Wörner, G., 2001. Source of fluids in the mantle wedge below Kamchatka, evidence from across-arc geochemical variation. Journal of Petrology 42, 1567-1593.

Daly, J.S. Balagansky, V.V., Timmerman, M.J. Whitehouse, M.J., de Jong, K., Guise, P, Bogdanova, S., Gorbatschev, $\mathrm{R} \&$ Bridgwater, D., 2001. Ion microprobe U-Pb zircon geochronology and isotopic evidence for a trans-crustal suture in the Lapland-Kola Orogen, northern Fennoscandian Shield. Precambrian Research 105, 289-314

Dasgupta, S., Sengupta, P., Ehl, J., Raith, M. \& Bardhan, S., 1995. Reaction textures in a suite of spinel granulites from the Eastern Ghats Belt, India: evidence for polymetamorphism, a partial petrogenetic grid in the systemKFMASH and the role of $\mathrm{ZnO}$ and $\mathrm{Fe}_{2} \mathrm{O}_{3}$. Journal of Petrology 36, 435-461.

Eskola, P., 1952. On the granulites of Lapland. American Journal of Science, Bowen volume 1, 133-171.

Essene, E.J., 1989. The current status of thermobarometry in metamorphic rocks. In Daly, J.S., Cliff, R.A. \& Yardley, B.W.D. (eds.) Evolution of metamorphic belts. Geological Society Special Publication 43, 1-44.

Gaál, G. \& Gorbatschev, R., 1987. An outline of the Precambrian evolution of the Baltic Shield. Precambrian Research 35, 15-52.

Ghent, E.D. \& Gordon, T.M., 2000. Application of INVQ to the geothermobarometry of metamorphic rocks near a kyanite-sillimanite isograd, Mica Creek, British Columbia. American Mineralogist, 85, 9-13.

Gordon, T.M., 1992. Generalized thermobarometry; Solution of the inverse chemical equilibrium problem using data for individual species. Geochimica et Cosmochimica Acta, 56, 1793-1800.

Gordon, T.M., Aranovich, L.Ya. \& Fed'kin, V.V., 1994. Exploratory data analysis in thermobarometry: an example from the Kisseynew Sedimentary Gneiss Belt, Manitoba, Canada. American Mineralogist, 79, 973-982.

Hackman, V., 1905. Die chemische Beschaffenheit von Eruptivgesteinen Finlands und der Halbinsel Kola. Bulletin de la Commission Géologique de Finlande 15, 143 p.

Hall, J., Wardle, R.J., Gower, C.F., Kerr, A., Coflin, K., Keen, C.E. \& Carrol, P., 1995. Proterozoic orogens of the northeastern Canadian Shield: new information from the Lithoprobe ESCOOT crustal reflection seismic survey. Canadian Journal of Earth Sciences 32, 1119-1131.

Harley, S.L., 1989. The origin of granulite: a metamorphic perspective. Geological Magazine 126, 215-147.

Hoffman, P.F., 1988. United plates of America, the birth of a craton: Early Proterozoic assembly and growth of Laurentia. Annual Rewievs of Earth and Planetary Sciences $16,543-603$.

Hoffman, P.F., 1989. Precambrian geology and tectonic history of North America. In: Bally, A.W. \& Palmer,
A.R. (eds.) The Geology of North America-An Overview. Geological Society of America, Boulder, Colorado, p. 447-512.

Hochstaedter, A.J., Gill, J., Peters, P., Broughton, P., Holden, P. \& Taylor, B., 2001. Across-arc geochemical trends in the Izu-Bonin arc: Contributions from the subducting slab. Geochemistry, Geophysics, Geosystems 2, Paper number 2000GC000105

Holtz, F., Johannes, W. Tamic, N. \& Behrens, H., 2001. Maximum and minimum water contents of granitic melts generated in the crust: a reevaluation and implications. Lithos 56, 1-14.

Hörmann, P.K., Raith, M., Raase, P., Ackermand, D. \& Seifert, F., 1980. The granulite complex of Finnish Lapland: petrology and metamorphic condidions in the Ivalojoki-Inarijärvi area. Geological Survey of Finland, Bulletin 308, $100 \mathrm{p}$.

Huhma, H., 1986. Sm-Nd, U-Pb and Pb-Pb isotopic evidence for the origin of the Early Proterozoic Svecokarelian crust in Finland. Geological Survey of Finland, Bulletin $337,48 \mathrm{p}$.

Huhma, H. \& Meriläinen, K.,1991. Provenance of paragneisses from the Lapland granulite belt. In Tuisku, P. \& Laajoki, K. (eds.) Metamorphism, deformation and structure of the crust, abstracts (IGCP 275). Res Terrae, Series A, No.5, p. 26.

Jolly, W.T., Lidiak, E.G., Dickin, A.P. \& Wu, T.-W., 2001. Secular geochemistry of Central Puerto Rican island arc lavas: Constraints on Mesozoic tectonism in the Eastern Greater Antilles. Journal of Petrology 42, 2197-2214.

Kesola, R., 1995. Näätämö. Explanation to the Geological map of Finland 1:100 000, pre-Quarternary rocks, sheets $3934+4912+4914$. Geological Survey of Finland, 88 p. (in Finnish with English summary)

Korja, T., Tuisku, P., Pernu, T. \& Karhu, J., 1996. Field, petrophysical and carbon isotope studies on the Lapland Granulite Belt: implications for deep continental crust. Terra Nova 8, 48-58.

Korsman, K., Koistinen, T., Kohonen, J., Wennerström, M., Ekdahl, E., Honkamo, M. Idman, H. \& Pekkala, Y. (eds.), 1997. Suomen kallioperäkartta/Bedrock map of Finland, 1:1 000 000. Geological Survey of Finland, Espoo.

Kröner, A., Puustinen, K. \& Hickman, M., 1981. Goechronology of an Archaean tonalitic gneiss dome in northern Finland andits relation with an unusual overlying volcanic conglomerate and komatiitic greenstone. Contributions to Mineralogy and Petrology 76, 33-41.

Le Breton, N. \& Thompson, A.B., 1988. Fluid-absent (dehydration) melting of biotite in metapelites in the early stages of crustal anatexis. Contributions to Mineralogy and Petrology 99, 226-237.

Leibinger, S., 1996. The North-Eastern Marginal Zone of the Lapland Granulite Belt at Kaamanen, Northern Finland: Lithology and Tectono-Metamorphic Development. Unpublished Graduate Thesis, Johann-Wlfgang- 
Goethe-Universität, Frankfurt, 95 p.

Lehtonen, M.. Manninen, T., Rastas, P. \& Räsänen, J., 1992. On the Early Proterozoic metavolcanic rocks in Finnish central Lapland. In: Mitrofanov, F. (ed.) Correlation of Precambrian Formations of the Kola-Karelia Region and Finland. Russian Academy of Science, Apatity, p. 65-85.

Leybourne, M.I., Van Wagoner, N. \&Ayres, L.D., 1999. Partial melting of refractory subducted slab in Palaeoproterozoic island arc: Implications for global chemical cycles. Geology 27, 731-734.

Marker, M., 1988. Early Proterozoic thrusting of the Lapland Granulite Belt and its geotectonic evolution, northern Baltic Shield. Geologiska Föreninge i Stockholm Förhandlingarna 110, 405-410.

McDonough, W.F., 1991. Partial melting of subducted oceanic crust and isolation of its residual eclogitic lithology. Royal Society of London Philosophical Transactions, Ser. A 335, 407-418.

Meriläinen, K., 1965. Geological Map of Finland 1:400 000, Sheet C8-9. Geological Survey of Finland.

Meriläinen, K., 1976. The granulite complex and adjacent rocks in Lapland, northern Finland. Geological Survey of Finland, Bulletin 281, 129 p.

Mikkola, E., 1937. Geological Map of Finland 1:400 000, Sheet C7. Geological Survey of Finland.

Mikkola, P., 1998. The pressure-temperature conditions of metamorphism of the Lapland granulite belt and their tectonic consequences (in Finnish). M.Sc Thesis, University of Oulu, Finland, 79 p.

Muhongo, S. \& Tuisku, P., 1996. Pan-African high pressure isobaric cooling : evidence from mineralogy and thermobarometry of the granulite-facies rocks from the Uluguru Mountain Ranges, eastern Tanzania. Journal of African Earth Sciences 23, 443-463.

Newton, R.C., 1987. Petrologic aspects of Precambrian granulite facies terrains bearing on their origins. In: Kröner, A. (ed.) Proterozoic Lithospheric Evolution, Geodynamic Series Vol. 17, AGU, Washington, p. 11-26.

Pattison, D.R.M. \& Tracy, R.J., 1991. Phase equilibria and thermobarometry of metapelites. In: Kerrick, D.M. (ed.) Contact Metamorphism. Mineralogical Society of America, Reviews in Mineralogy 26, 105-206.

Pearce, J. A., 1983. Role of the sub-continental lithosphere in magma genesis at active continental margins. In: Hawkesworth, C.J. (ed.) Continental basalts and mantle xenoliths. Shiva, United Kingdom, 230-249.

Perchuk, L.L., Gerya, T.V., van Reenen, D.D., Krotov, A.V., Safonov, O.G., Smit, C.A. \& Shur, M.Yu., 2000. Comparative petrology and metamorphic evolution of the Limpopo (South Africa) and Lapland (Fennoscandia) high grade terrains. Mineralogy and Petrology, 69, 69-107.

Pëto, P., 1976. An experimental investication of melting reactions involving muscovite and paragonite in the silicasaturated portion of the system $\mathrm{K}_{2} \mathrm{O}-\mathrm{Na}_{2} \mathrm{O}-\mathrm{Al}_{2} \mathrm{O}_{3}-\mathrm{SiO}_{2}-$
$\mathrm{H}_{2} \mathrm{O}$ to $15 \mathrm{kbar}$ total pressure. Programs in Experimental Petrology, Natural Environment Research Council $3^{\text {rd }}$ report, 41-45.

Raith, M. \& Raase, P., 1986. High grade metamorphism in the granulite belt of Finnish Lapland. In: Dawson, J.B. et al. (eds.) The Nature of the Lower Continental Crust. Geological Society of London, Special Publication 24, 283-295.

Sengupta, P., Karmakar, S., Dasgupta, S. \& Fukuoka, M., 1991. Petrology of spinel granulites from Araku, Eastern Ghats, India, and a petrogenetic grid for sapphirinefree rocks in the system FMASH. Journal of Metamorphic Geology 9, 451-459.

Sengupta, P., Sen, J., Dasgupta, S., Raith, M., Bhui, U.K. \& Ehl, J., 1999. Ultra-high temperature metamorphism of metapelitic granulites from Kondapalle, Eastern Ghats Belt: implications for the Indo-Antarctic correlation. Journal of Petrology 40, 1065-1087.

Shinjo, R., Woodhead, J.D. \& Hergt, J.M., 2000. Geochemical variation within the northern Ryukyu Arc: magma source composition and geodynamic implications. Contributions to Mineralogy and Petrology 137, 323-341.

Simonen, A., 1980. Pre-Quarternary Rocks of Finland 1: 1000 000. Geological Survey of Finland.

Sorjonen-Ward, P., Claoué-Long J. \& Huhma H., 1994. SHRIMP isotope studies of granulite zircons and their relevance to early Proterozoic tectonics in northern Fennoscandia. U.S.G.S. Circular 1107, p. 299.

Spear, F.S., 1993. Metamorphic Phase Equilibria and Pressure-Temperature-Time Paths. Washington D.C.: Mineralogical Society of America Monograph Series.

Thompson, A.B., 1982. Dehydration melting of pelitic rocks and the generation of $\mathrm{H}_{2} \mathrm{O}$-undrsaturated granitic liquids. American Journal of Science 276, 1567-1595.

Thomson, J.A., 2001. A counterclockwise P-T path for anatectic pelites, south-central Massachusetts. Contributions to Mineralogy and Petrology 141, 623-641.

Tuisku, P. \& Huhma, H., 1998. Eclogite from the marginal zone of the Lapland granulite belt: evidence from the 1.90-1.88 Ga subduction zone. Geological Survey of Finland, Special Paper 26, p. 61.

Tuisku, P. \& Huhma, H., 1999. SIMS U-Pb dating of zircons from migmatite khondalites and enderbite from Lapland granulite belt, Finland. Terra Abstracts 11, 710-711.

Tuisku, P. \& Makkonen, H.V., 1999. Spinel-bearing symplectites in Palaeoproterozoic ultramafic rocks from two different geological settings in Finland: thermobarometric and tectonic implications. Geologiska Förening i Stockholm Förhandlingarna 121, 293-300.

Tuttle, O.F. \& Bowen, N.L., 1958. Origin of granite in the light of experimental studies in the system $\mathrm{NaAl}-$ $\mathrm{Si}_{3} \mathrm{O}_{8}-\mathrm{KalSi}_{3} \mathrm{O}_{8}-\mathrm{SiO}_{2}-\mathrm{H}_{2} \mathrm{O}$. Geological Society of America Memoir 74, 54-63.

Vaasjoki, M., (ed.), 2001. Radiometric age determinations 
from Finnish Lapland and their bearing on the timing of

Precambrian volcano-sedimentary sequences. Geological

Survey of Finland, Special Paper 33, 279 p. 